\title{
Article \\ A Half Century of Research on Childhood and Adolescent Depression: Science Mapping the Literature, 1970 to 2019
}

\author{
Mi Zhou, Biyu Bian, Weiming Zhu and Li Huang * (1) \\ College of Economics and Management, Shenyang Agricultural University, Shenyang 110866, Liaoning, China; \\ zhoumi2011@syau.edu.cn (M.Z.); 2019220618@stu.syau.edu.cn (B.B.); 2020200182@stu.syau.edu.cn (W.Z.) \\ * Correspondence: lilyhuang@syau.edu.cn
}

Citation: Zhou, M.; Bian, B.; Zhu, W. Huang, L. A Half Century of

Research on Childhood and

Adolescent Depression: Science Mapping the Literature, 1970 to 2019. Int. J. Environ. Res. Public Health 2021, 18, 9524. https://doi.org/10.3390/ ijerph18189524

Academic Editor: Roger C.M. Ho

Received: 24 July 2021

Accepted: 7 September 2021

Published: 9 September 2021

Publisher's Note: MDPI stays neutral with regard to jurisdictional claims in published maps and institutional affiliations.

Copyright: (c) 2021 by the authors. Licensee MDPI, Basel, Switzerland. This article is an open access article distributed under the terms and conditions of the Creative Commons Attribution (CC BY) license (https:// creativecommons.org/licenses/by/ $4.0 /)$.

\begin{abstract}
In order to gain an in-depth understanding of research about childhood and adolescent depression, this article analyzes the scale, development, and geographic distribution of the literature in the field based on 8491 articles extracted from the Web of Science Core database. Using citation analysis, this article identifies influential journals, scholars, and documents in this field. The study found that in the past 15 years, the number of documents has increased significantly and geographical diversity has also increased. Most of the highly influential literature relates to depression inventories. Using keyword co-occurrence analysis, this article also identified three key research topics focusing on (a) child and adolescent depression symptoms and prevalence, (b) parental depression and child behavioral or emotional problems, and (c) childhood abuse and depression. This study uses 'science mapping' as a means to provide a better understanding of research trends about childhood and adolescent depression that have emerged over the past half century, and may serve as reference for future research.
\end{abstract}

Keywords: depression; children; adolescents; science mapping; bibliometric analysis

\section{Introduction}

Depression is defined as a cluster of specific symptoms with associated impairment. The clinical and diagnostic features of the disorder are broadly similar in adolescents and adults [1-3]. The first article on depression in children and adolescents was published in 1934 by Schumacher. In his paper, he stated that depression had serious and long-lasting effects on mental health in both children and adults. Morbidity rates had become very high, and it was time for constructive work in the field of mental healthcare [4]. Before the 1970s, child psychiatry and psychology literature contained relatively few references to depression. Discussion of depression in children centered around the question of whether or not it existed [5]. Depression in children began to attract attention from researchers after the 1970s [6,7]. Early studies discussed the nature and characteristics of depression in childhood [6,8], the classification of childhood depression [9,10], the recognition of depressive disorders in children [11], and methods of measuring childhood depression [12,13]. In general, before the 1980s, studies on childhood depression still lacked using methodological techniques such as systematic rating scales and structured interviews for children analogous to those that have been developed for adults [14]. Since 1980s, more measurement scales were developed and studies of depression in children became more common.

Some empirical and qualitative reviews by experts have offered an overview of childhood and adolescent depression research, providing qualitative reviews of research on depression in children and adolescents from multiple perspectives, including epidemiology, family factors, individual characteristics, and treatment [15-18]. However, it is difficult to effectively organize, summarize, and quantitatively analyze the development of a specific field among a large number of studies on a large time scale in traditional review articles. Bibliometric analysis can effectively describe the knowledge status, features, and trends 
in a certain discipline and help people who are interested in but unfamiliar with this field to quickly grasp its basic status. This technique has been widely used to measure the performance of various disciplines $[19,20]$. Additionally, knowledge graphs combine information visualization technology with traditional scientometrics citation analysis to visually display the knowledge of a subject or field through data mining, information processing, scientific measurement, and graphic drawing [21,22].

The purpose of this paper is to gain an empirically-based perspective on the evolution of the childhood and adolescent depression knowledge base over a period of 50 years. We address the following three questions: (1) What is the growth trajectory and geographic distribution of the literature about childhood and adolescent depression published between 1970 and 2019? (2) Which journals, authors and articles were most influential during this period? (3) What topics have attracted the most attention from scholars in this field over the past 50 years?

Specifically, this paper examines the literature on childhood depression included in Web of Science (WoS) core database from 1970 to 2019 and conducts a simple statistical analysis to obtain the basic development law and regional distribution of the literature on childhood depression. This paper also uses descriptive statistics, citation analysis and co-citation analysis to display the productive journals, core authors, and important literature in the field of childhood depression research, and makes a visual analysis of the co-occurrence network of key words in studies on childhood depression with the help of VOSviewer software. Additionally, this paper combines analysis of the visualization results and the literature to dig out the knowledge base and research hotspots in the field of childhood depression. Finally, the paper summarizes the results of the bibliometric analysis and gives suggestions for future research.

\section{Methodology}

The methods that used for bibliometric analysis include descriptive statistics, citation analysis, co-citation analysis, and co-occurrence analysis [23]. Scholars have used citation analysis to identify well-known authors, documents and journals in a certain field of knowledge [24-26]. Co-citation analysis can 'capture' some important documents by mining the reference list of documents in a certain database. It therefore provides a broader method of measuring academic influence than traditional citation analysis. This article uses MS Excel and WoS analysis tools to perform descriptive statistical analysis of trends in the literature (such as the number of articles classified by country, author, and journal). This article also uses ArcGIS to create a heat map showing the geographic distribution of documents. It also uses citation analysis to determine the extent to which authors and documents in the database had been cited. Document co-citation analysis (DCA) is used to identify influential articles. Finally, this study uses the freely accessible text mining software VOSviewer to analyze and visualize the literature on child and adolescent depression from the perspectives of authors, citations, and keywords.

Data collection is a crucial part of bibliometric analysis. The academic database Web of Science (WoS) covers nearly 150 research disciplines and contains over 12,000 influential academic journals that are widely recognized by the international academic community [27]. The literature used in this study comes from the "Science Citation Index Extension (SCIE)" and "Social Science Citation Index (SSCI)" databases of the "Web of Science Core Collection". On 30 August 2021, an advanced search was performed in WoS using the following search string: $\mathrm{TI}=(($ depression AND child $*)$ or (depressive symptom $*$ AND

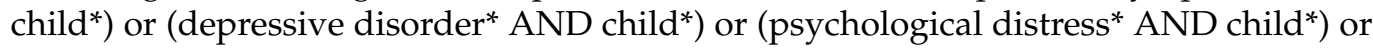
(mood disorder* AND child*) or (depression AND adolescen*) or (depressive symptom* AND adolescen*) or (depressive disorder* AND adolescen*) or (psychological distress* AND adolescen*) or (mood disorder* AND adolescen*)). The topic field retrieval, which includes the fields "Title", "Abstract", and "Keywords", was not used. This allows the study to avoid the occurrence of non-related results. The timespan was set from 1970 
to 2019. The retrieved document records provided several fields, including title, author, abstract, source publication, citations, and references.

\section{Results}

\subsection{Volume, Growth Trajectory, and Geographic Distribution of the Literature}

The sample in this study is comprised of 8491 articles by 24,950 authors affiliated with 4510 institutions in 113 countries. These articles were published in 1240 journals and included 175,363 cited references.

The number of papers published can provide an important reference for the study of the development characteristics and laws of a certain field during a certain period. Figure 1 illustrates the annual number and the citation volume of articles on childhood and adolescent depression. In general, the number of articles on child and adolescent depression has increased significantly from the initial 3 in 1970 to 824 in 2019 . However, as can be seen from the figure, the number of annual articles published did not increase yearly from 1970-2019. Meanwhile, 2019 was the year with the most published studies of childhood and adolescent depression (824 articles published).

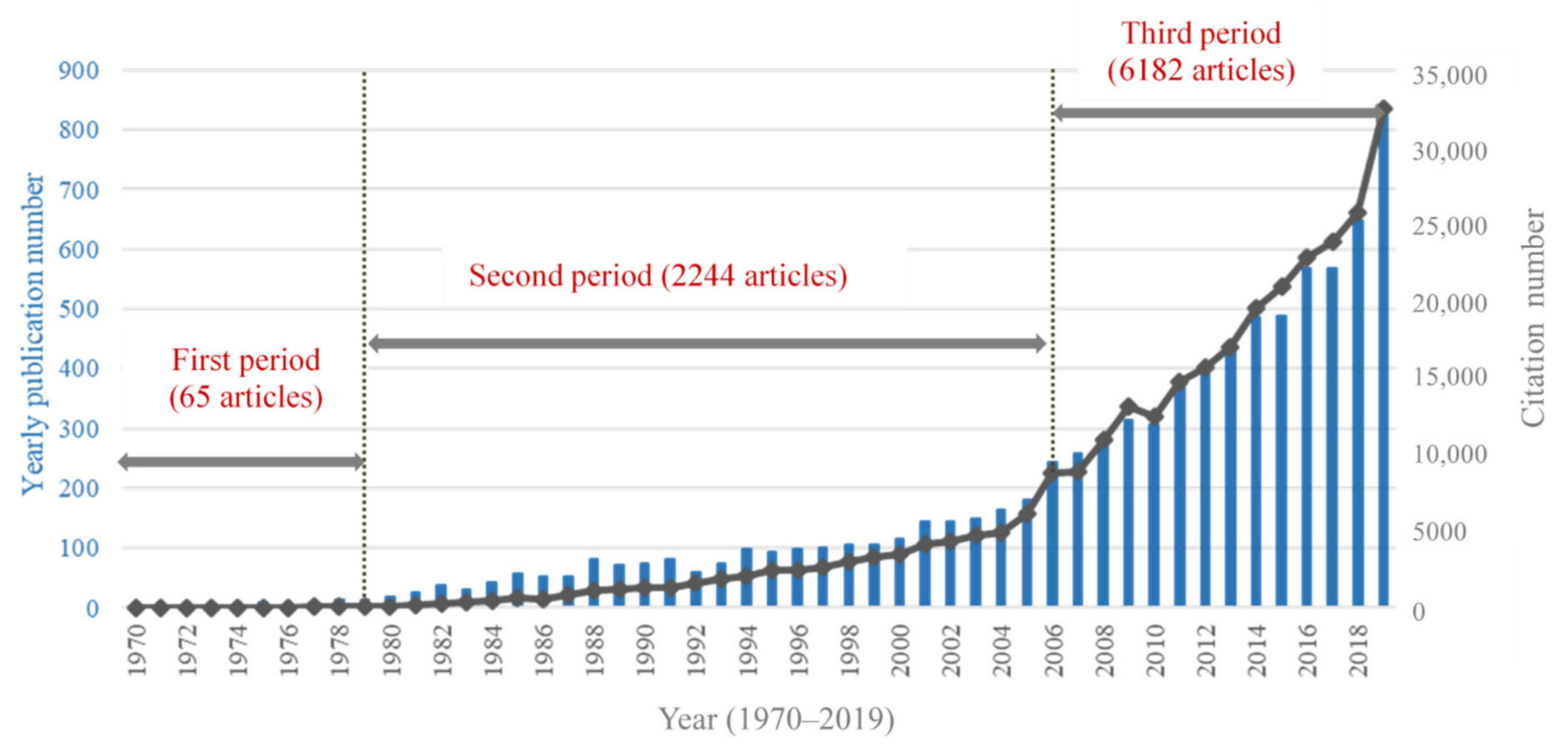

Figure 1. Trends in the quantity of articles identified by Web of Science (WoS) that are related to childhood and adolescent depression and published between 1970 and 2019.

We compared the annual publication volume (Figure 1), dividing the years into the following three stages: 1970-1979, 1980-2005, and 2006-2019. Only a handful of studies were published in each year before 1980 (an average of 6.5 articles per year from 1970-1979). However, an upward trend can be observed after 1980 (with an average of 86.3 articles per year from 1980-2005). The number of published articles exceeded 200 for the first time in 2006 , and has continued to increase significantly (with an average of 441.57 articles per year from 2006-2019).

Figure 2 shows the geographic distribution of articles published since 1970 on childhood and adolescent depression. Darker colors signify higher rates of publication. The map shows the dominance of the United States, which accounts for nearly half of the documents in the database. Among the countries that published more than 100 articles, there are two North American countries, eight European countries, four Asian countries, and Australia. Articles about childhood and adolescent depression are mainly concentrated in the United States, England, Canada, Australia, China, Netherlands, and Germany. 


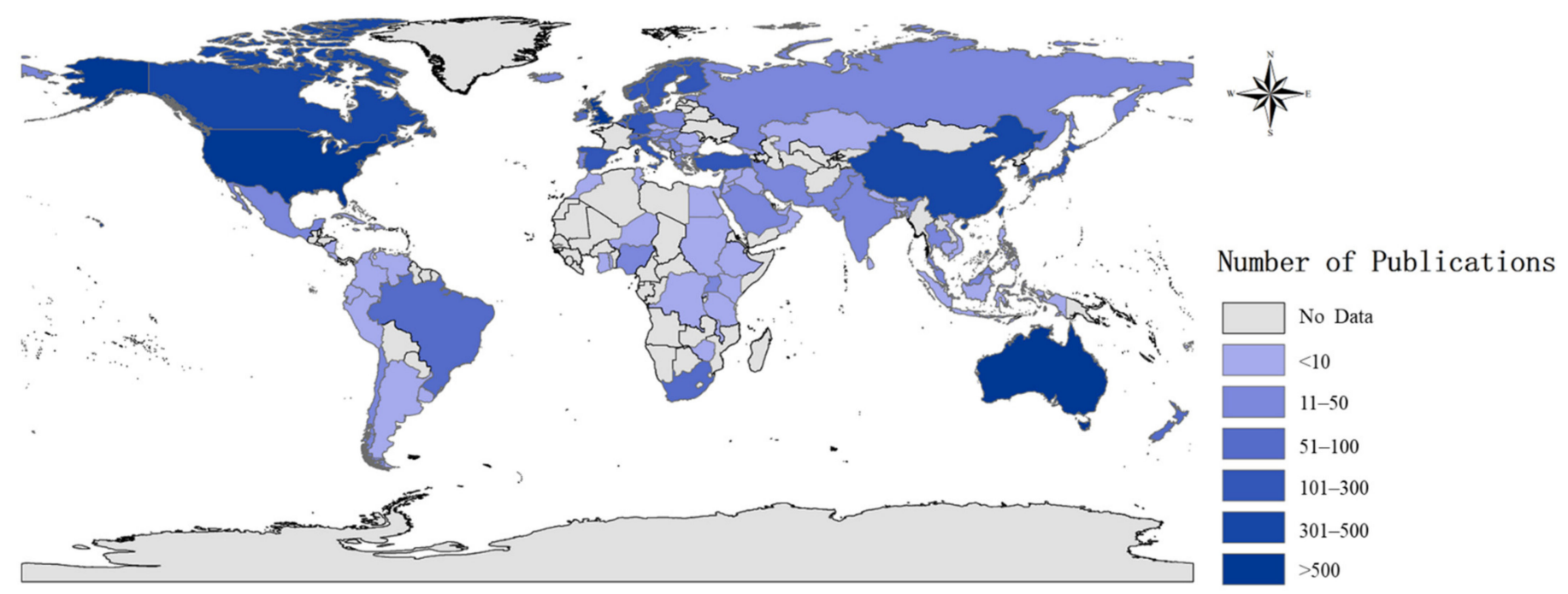

Figure 2. Global distribution of the childhood and adolescent depression literature, 1970 to 2019.

\subsection{Influential Journals, Authors, and Documents}

\subsubsection{Journal Analysis}

There were 1240 journals that published studies on depression in children and adolescents between 1970 and 2019. Table 1 lists the top ten journals in terms of publication volume. The Journal of Affective Disorders (352) is the most active journal, followed by Journal of The American Academy of Child and Adolescent Psychiatry (299), Journal of Abnormal Child Psychology (240), and Journal of Youth and Adolescence (163). Articles in the field of childhood and adolescent depression have been published primarily in these major journals. Specifically, the journals in Table 1 (accounting for less than $1 \%$ of 1240 journals) published a total of 1759 articles, accounting for $20.7 \%$ of the total 8491 articles.

Table 1. Top 10 most active journals publishing on childhood and adolescent depression.

\begin{tabular}{|c|c|c|c|c|}
\hline Journal Title & $\begin{array}{l}\text { Number of } \\
\text { Publications }\end{array}$ & IF $^{\mathbf{a}}$ & H-Index & $\begin{array}{l}\text { Subject Category of the Journal } \\
(2020)\end{array}$ \\
\hline Journal of Affective Disorders & 352 & 5.515 & 59 & $\begin{array}{l}\text { Clinical Neurology (Q2) } \\
\text { Psychiatry (Q1) }\end{array}$ \\
\hline $\begin{array}{l}\text { Journal of The American Academy of Child } \\
\text { and Adolescent Psychiatry }\end{array}$ & 299 & 10.606 & 95 & $\begin{array}{c}\text { Pediatrics (Q1) } \\
\text { Psychiatry (Q1) } \\
\text { Psychology, Developmental (Q1) }\end{array}$ \\
\hline Journal of Abnormal Child Psychology & 240 & 4.836 & 67 & $\begin{array}{c}\text { Psychology, Clinical (Q2) } \\
\text { Psychology, Developmental (Q1) }\end{array}$ \\
\hline Journal of Youth and Adolescence & 163 & 5.613 & 45 & Psychology, Developmental (Q1) \\
\hline $\begin{array}{l}\text { Journal of Clinical Child and Adolescent } \\
\text { Psychology }\end{array}$ & 146 & 5.644 & 45 & $\begin{array}{l}\text { Psychology, Clinical (Q1) } \\
\text { Psychology, Developmental (Q1) }\end{array}$ \\
\hline Journal of Adolescence & 120 & 4.181 & 39 & $\begin{array}{c}\text { Psychology, Developmental (Q2) } \\
\text { Psychiatry (Q1) }\end{array}$ \\
\hline Journal of Child Psychology and Psychiatry & 118 & 9.917 & 55 & $\begin{array}{c}\text { Psychology (Q1) } \\
\text { Psychology, Developmental (Q1) }\end{array}$ \\
\hline Development and Psychopathology & 111 & 5.643 & 40 & $\begin{array}{c}\text { Psychology, Developmental (Q1) } \\
\text { Family Studies (Q2) }\end{array}$ \\
\hline Journal of Child and Family Studies & 110 & 2.91 & 18 & $\begin{array}{c}\text { Psychiatry (Q3) } \\
\text { Psychology, Developmental (Q3) }\end{array}$ \\
\hline Journal of Abnormal Psychology & 100 & 8.756 & 60 & $\begin{array}{c}\text { Psychiatry (Q1) } \\
\text { Psychology Clinical (Q1) }\end{array}$ \\
\hline
\end{tabular}

Note: IF ${ }^{a}$ : Five-year impact factor, impact factor data from the 2020 edition of Journal Citation Reports ${ }^{\circledR}$ in Web of Science. 
The impact factor (IF) and H-index of journals measure their value according to their role and status in scientific communication. Among the top-10 most productive journals, Journal of The American Academy of Child and Adolescent Psychiatry is the most influential in terms of IF and H-index (10.606 and 95), followed by Journal of Child Psychology and Psychiatry (9.917 and 55), and Journal of Abnormal Child Psychology (8.756 and 60). As shown in Table 1, each journal belongs to at least one of the following categories: Clinical Neurology, Psychiatry, Psychology Developmental, Psychology Clinical, Family Studies, Psychology Social, Social Work, or Psychology. Therefore, we can see that the study of childhood and adolescent depression is mainly concentrated in the fields of psychology, sociology and psychiatry.

\subsubsection{Author and Co-Authorship Analysis}

"Author-based studies" have been one of the most important contributions of bibliometrics [28]. In practice, scholars identify prolific scholars based on the number of published papers and evaluate the academic influence based on the number of citations an author receives. The number of authors in the original download data is 25,569 . Since there are sometimes multiple ways to write an author's name (such as Kovacs, Maria and Kovacs, M. etc.), it is necessary to replace the author's name while merging the information. With the help of the auxiliary function of the VOSviewer software (as a free piece of software, VOSviewer can be downloaded from the website https:/ / www.vosviewer.com/download (accessed on 11 October 2020)), this study was carried out by two authors to ensure data accuracy. The final number of authors was 24,950 . Table 2 lists the top 20 scholars by the number of citations and articles. Meanwhile, the number of average citations and $\mathrm{H}$-index are analyzed to identify the most influential authors in the field.

Table 2. Ranking of the 20 most highly cited authors, 1970 to 2019.

\begin{tabular}{|c|c|c|c|c|c|c|}
\hline Author & Country/Institute & Active & Citations $^{a}$ & Numbers & $\begin{array}{c}\text { Average } \\
\text { Citations Per } \\
\text { Publication }\end{array}$ & H-Index \\
\hline Seeley, JR & USA/Oregon Research Institute & 1991-2014 & 8258 & 50 & 165.2 & 40 \\
\hline Kovacs, M & USA/University of Pittsburgh & 1981-2019 & 8064 & 47 & 171.77 & 33 \\
\hline Lewinsohn, PM & USA/Oregon Research Institute & 1990-2014 & 7864 & 51 & 172.06 & 40 \\
\hline Birmaher, B & USA/University of Pittsburgh & $1992-2018$ & 6434 & 70 & 91.94 & 44 \\
\hline Ryan, ND & USA/University of Pittsburgh & 1986-2019 & 4945 & 56 & 88.32 & 38 \\
\hline Pine, DS & $\begin{array}{l}\text { USA/National Institute of Mental Health } \\
\qquad(\mathrm{NIMH})\end{array}$ & 1998-2019 & 3939 & 20 & 196.95 & 18 \\
\hline Emslie, GJ & $\begin{array}{l}\text { USA/University of Texas Southwestern } \\
\text { Medical Center Dallas }\end{array}$ & 1987-2018 & 3862 & 54 & 71.56 & 31 \\
\hline Hammen, $\mathrm{C}$ & USA/University of California Los Angeles & 1984-2016 & 3623 & 36 & 100.72 & 31 \\
\hline Brent, DA & USA/University of Pittsburgh & 1987-2018 & 3619 & 42 & 86.31 & 32 \\
\hline Garber, J & USA/Vanderbilt University & 1980-2019 & 3603 & 44 & 82.02 & 28 \\
\hline Cole, DA & USA/Vanderbilt University & 1986-2019 & 3527 & 49 & 71.98 & 33 \\
\hline Klein, DN & $\begin{array}{c}\text { USA/State University of New York Stony } \\
\text { Brook }\end{array}$ & 1994-2019 & 3327 & 48 & 69.33 & 27 \\
\hline Dahl, RE & USA/University of California Berkeley & 1990-2019 & 3109 & 41 & 75.83 & 28 \\
\hline Weissman, MM & USA/Columbia University & 1980-2019 & 3005 & 26 & 115.58 & 21 \\
\hline Wagner, KD & $\begin{array}{c}\text { USA/University of Texas Medical Branch } \\
\text { Galveston }\end{array}$ & 1993-2014 & 2902 & 35 & 86.46 & 23 \\
\hline Hankin, BL & USA/University of Illinois Urbana-Champaign & 2001-2019 & 2775 & 37 & 72.92 & 24 \\
\hline Asarnow, JR & USA/University of California Los Angeles & 1985-2019 & 2757 & 43 & 64.98 & 26 \\
\hline McCauley, E & USA/University of Washington & 1988-2017 & 2625 & 42 & 62.50 & 27 \\
\hline Thapar, A & England/Cardiff University & 1994-2019 & 2257 & 38 & 60.68 & 20 \\
\hline Compas, BE & USA/Vanderbilt University & 1993-2019 & 2229 & 32 & 67.88 & 19 \\
\hline
\end{tabular}

${ }^{a}$ : citations are based on citations by other documents contained in the WoS index as of 30 August 2021.

It can be found that Seeley, JR, from Oregon Research Institute (USA), is the author with the most citations (8258) and the largest number of articles on childhood and adolescent depression (50). It is noteworthy that 19 of the 20 authors in Table 2 are from the United States. With regards to average number of citations, it can be found that Lewinsohn, PM, who is also from Oregon Research Institute, had made the greatest contribution to the 
field. Of the 20 authors, 11 have been active in the area of childhood depression for more than 30 years and 19 have been active for over 20 years. There are 17 authors who are still engaged in this research (meaning that they have published new articles in the field since 2016).

Here, we use co-author network analysis to highlight author cooperation in the study of childhood and adolescent depression. The minimum number of documents for an author was set as 20. Of the 24,950 authors, 61 met this threshold. The clustering function of VOS viewer software divides these authors into five categories and each cluster is marked with a different color. As shown in Figure 3, Garber, J contributes to the most documents with others (links = 59), followed by Klein, DN (links = 58), Kovacs, $\mathrm{M}($ links = 57), and Emslie, GJ (links = 57).

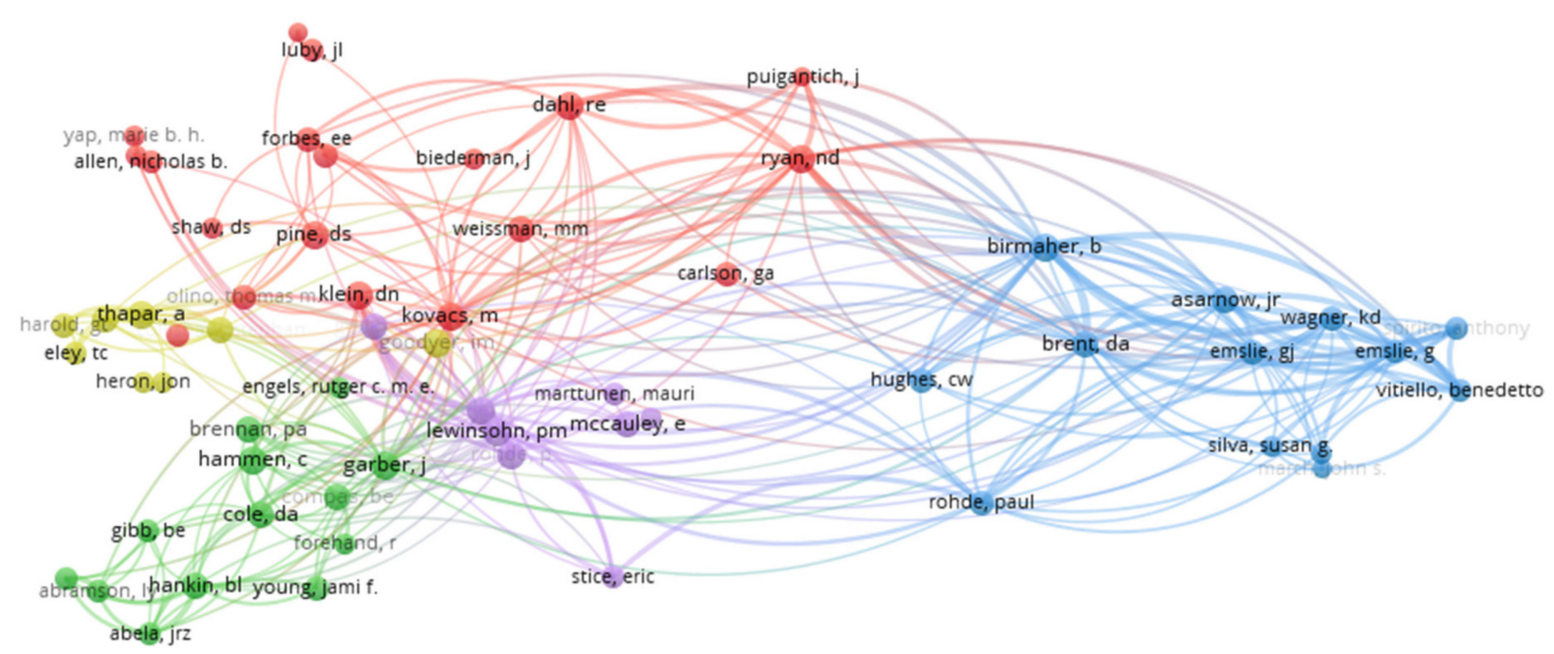

Figure 3. The co-authorship network for studies of child and adolescent depression, from 1970 to 2019 (threshold 20 articles, display 61 authors).

\subsubsection{Citation and Co-Citation Analysis of Documents}

In this section, we will focus on analyzing the most highly cited and co-cited documents. A total of 20 of the articles published from 1970-2019 have 570 or more citations (see Table 3). These highly-cited documents were published between 1981 and 2012. Six authors in Table 2 appear among the authors of the highly-cited articles listed in Table 3, and 7 of the 20 articles listed in Table 3 were authored (or co-authored) by scholars listed in Table 2.

Most of these highly-cited articles were concerned with "depression inventory" [29-36]; There have also been many studies of "childhood abuse or trauma and depression" and "adverse childhood experiences and depression" [37-40]. In addition, studies on the symptoms, characteristics, prevalence, and treatment of depression in children and adolescents also appear in Table 3.

Table 3. Ranking of the 20 most highly cited articles, 1970 to 2019.

\begin{tabular}{ccc}
\hline Rank & Document & Topic $^{\text {Citations }}{ }^{\text {a }}$ \\
\hline 1 & Kovacs, M. (1985) [30]. The Children's Depression Inventory \\
(CDI) & Depression Inventory \\
\hline 2 & Kovacs, M. (1981) [29]. Rating-scales to assess depression in \\
school-aged children & Depression Inventory \\
\hline 3 & $\begin{array}{c}\text { Lewinsohn, P.M., Hops, H., Roberts, R.E., Seeley, J.R., Andrews, } \\
\text { J.A. (1993) [41]. Adolescent Psychopathology. 1. Prevalence and } \\
\text { Incidence of Depression and Other DSM-III-R Disorders in } \\
\text { High-School-Students }\end{array}$ & Depression Prevalence \\
\hline
\end{tabular}


Table 3. Cont.

\begin{tabular}{|c|c|c|c|}
\hline Rank & Document & Topic & Citations $^{a}$ \\
\hline 4 & $\begin{array}{c}\text { Radloff, L.S. (1991) [31]. The Use of The Center for } \\
\text { Epidemiologic Studies Depression Scale in Adolescents and } \\
\text { Young-Adults }\end{array}$ & Depression Inventory & 1236 \\
\hline 5 & $\begin{array}{c}\text { Chapman, D.P., Whitfield, C.L., Felitti, V.J., Dube, S.R., Edwards, } \\
\text { V.J., Anda, R.F. (2004) [37]. Adverse childhood experiences and } \\
\text { the risk of depressive disorders in adulthood }\end{array}$ & $\begin{array}{l}\text { Childhood Abuse and } \\
\text { Depressive Disorders }\end{array}$ & 1153 \\
\hline 6 & $\begin{array}{l}\text { Pine, D.S., Cohen, P., Gurley, D., Brook, J. (1998) [42]. The risk } \\
\text { for early-adulthood anxiety and depressive disorders in } \\
\text { adolescents with anxiety and depressive disorders }\end{array}$ & Depression Risk & 1148 \\
\hline 7 & $\begin{array}{c}\text { Angold, A., Costello, E.J., Messer, S.C., Pickles, A. (1995a) [34]. } \\
\text { Development of a short questionnaire for use in } \\
\text { epidemiological studies of depression in children and } \\
\text { adolescents }\end{array}$ & Depression Inventory & 1127 \\
\hline 8 & $\begin{array}{l}\text { Thapar, A., Collishaw, S., Pine, D.S., Thapar, A.K. (2012) [1]. } \\
\text { Depression in adolescence }\end{array}$ & $\begin{array}{l}\text { Depression Prevalence, Risk } \\
\text { and Prevention }\end{array}$ & 889 \\
\hline 9 & $\begin{array}{c}\text { Chorpita, B.F., Yim, L., Moffitt, C., Umemoto, L.A., Francis, S.E. } \\
\text { (2000) [35]. Assessment of symptoms of DSM-IV anxiety and } \\
\text { depression in children }\end{array}$ & Depression Inventory & 876 \\
\hline 10 & $\begin{array}{c}\text { Saylor, C.F., Finch, A.J., Spirito, A., Bennett, B. (1984) [32]. The } \\
\text { Children's Depression Inventory-A systematic evaluation of } \\
\text { psychometric properties }\end{array}$ & Depression Inventory & 817 \\
\hline 11 & $\begin{array}{c}\text { Cyranowski, J.M., Frank, E., Young, E., Shear, M.K. (2000) [43]. } \\
\text { Adolescent onset of the gender difference in lifetime rates of } \\
\text { major depression }\end{array}$ & Depression Prevalence & 726 \\
\hline 12 & $\begin{array}{l}\text { Emslie, G.J., Rush, A.J., Weinberg, W.A., Kowatch, R.A., } \\
\text { Hughes, C.W., Carmody, T., Rintelmann, J. (1997) [44]. A } \\
\text { double-blind, randomized, placebo-controlled trial of fluoxetine } \\
\text { in children and adolescents with depression }\end{array}$ & Depression Treatment & 708 \\
\hline 13 & $\begin{array}{c}\text { Whittington, C.J., Kendall, T., Fonagy, P., Cottrell, D., Cotgrove, } \\
\text { A., Boddington, E. (2004) [45]. Selective serotonin reuptake } \\
\text { inhibitors in childhood depression: systematic review of } \\
\text { published versus unpublished data }\end{array}$ & Depression Treatment & 696 \\
\hline 14 & $\begin{array}{l}\text { Nanni, V., Uher, R., Danese, A. (2012) [40]. Childhood } \\
\text { maltreatment predicts unfavorable course of illness and } \\
\text { treatment outcome in depression }\end{array}$ & $\begin{array}{l}\text { Childhood maltreatment and } \\
\text { Depression }\end{array}$ & 678 \\
\hline 15 & $\begin{array}{l}\text { Danese, A., Moffitt, T.E., Harrington, H., Milne, B.J., Polanczyk, } \\
\text { G., Pariante, C.M., Poulton, R., Caspi, A. (2009) [39]. Adverse } \\
\text { childhood experiences and adult risk factors for age-related } \\
\text { disease depression, inflammation, and clustering of metabolic } \\
\text { risk markers }\end{array}$ & $\begin{array}{l}\text { Adverse Childhood } \\
\text { Experiences and Depression }\end{array}$ & 653 \\
\hline 16 & $\begin{array}{l}\text { Widom, C.S., DuMont, K., Czaja, S.J. (2007) [38]. A prospective } \\
\text { investigation of major depressive disorder and comorbidity in } \\
\text { abused and neglected children grown up }\end{array}$ & $\begin{array}{l}\text { Childhood Abuse and } \\
\text { Depressive Disorders }\end{array}$ & 648 \\
\hline 17 & $\begin{array}{l}\text { Twenge, J.M., Nolen-Hoeksema, S. (2002) [36]. Age, gender, } \\
\text { race, socioeconomic status, and birth cohort differences on the } \\
\text { Children's Depression Inventory }\end{array}$ & Depression Inventory & 644 \\
\hline 18 & $\begin{array}{l}\text { Smucker, M.R., Craighead, W.E., Craighead, L.W., Green, B.J. } \\
\text { (1986) [33]. Normative and reliability data for the Children's } \\
\text { Depression Inventory }\end{array}$ & Depression Inventory & 621 \\
\hline
\end{tabular}


Table 3. Cont.

\begin{tabular}{|c|c|c|c|}
\hline Rank & Document & Topic & Citations $^{a}$ \\
\hline 19 & $\begin{array}{l}\text { Kovacs, M., Feinberg, T.L., Crousenovak, M.A., Paulauskas, S.L., } \\
\text { Finkelstein, R. (1984) [46]. Depressive-disorders in childhood }\end{array}$ & $\begin{array}{l}\text { Psychiatric Status and } \\
\text { Characteristics }\end{array}$ & 585 \\
\hline 20 & $\begin{array}{c}\text { Costello, E.J., Erkanli, A., Angold, A. (2006) [47]. Is there an } \\
\text { epidemic of child or adolescent depression? }\end{array}$ & Depression Prevalence & 575 \\
\hline
\end{tabular}

Next, VOSviewer software is used to determine the top co-cited documents in the field of childhood and adolescent depression (see Table 4). As mentioned above, because document co-citation analysis allows scholars to dig into documents outside the database, it can provide a useful and complementary perspective for traditional citation analysis. The top co-cited documents listed in Table 4 span a period of four decades. Of these, nine are conceptual studies and five are review articles. The earliest of these documents were authored by Beck [48], Radloff [49], and Kovacs [29]. Beck et al. [48] created the original depression inventory (Beck Depression Inventory (BDI)) to meet the need for a brief self-report measure. Radloff [49] proposed a self-reporting scale for measuring depressive symptoms in the general population-CES-D scale, which was a useful tool for epidemiological research on depression. Kovacs developed a self-reporting childhood and adolescent depression inventory in 1981, which became the most widely used self-reporting measure of depression and underwent thorough psychometric investigation.

There was some overlap with the highly cited documents displayed in Table $3[29,30,32]$. These articles were all produced in the 1980s and related to the child depression scale. However, as mentioned earlier, document co-citation analysis (DCA) confirmed a broader set of influential literature. The co-cited articles listed in Table 4 included not only those about depression, but also methodological-related literature [50]. There are even articles on modeling methods [51,52] and user guides for analytical software [53]. Unsurprisingly, Radloff's [49] Applied Psychological Measurement paper on the CES-D Scale, published over 40 years ago, emerged as the most influential article in the field.

Table 4. Twenty most highly co-cited documents, 1970 to 2019.

\begin{tabular}{|c|c|c|c|c|c|}
\hline Rank & Cited Reference & Year & Source & Paper Type & Co-Citations \\
\hline 1 & Radloff, L. S. The CES-D Scale [49]. & 1977 & $\begin{array}{l}\text { Applied Psychological } \\
\text { Measurement }\end{array}$ & Con & 1234 \\
\hline 2 & $\begin{array}{c}\text { American Psychiatric Association (APA). } \\
\text { Diagnostic and statistical manual of } \\
\text { mental disorders. }\end{array}$ & 1994 & $\begin{array}{l}\text { Washington DC: American } \\
\text { Psychiatric Association }\end{array}$ & - & 715 \\
\hline 3 & $\begin{array}{l}\text { Kovacs, M., Goldston, D., Obrosky, D.S. } \\
\text { Prevalence and predictors of pervasive } \\
\text { noncompliance with medical-treatment } \\
\text { among youths with insulin-dependent } \\
\text { diabetes-mellitus [53]. }\end{array}$ & 1992 & $\begin{array}{l}\text { Journal of The American } \\
\text { Academy of Child and } \\
\text { Adolescent Psychiatry }\end{array}$ & Emp & 493 \\
\hline 4 & $\begin{array}{l}\text { Kaufman, J., et al. Schedule for Affective } \\
\text { Disorders and Schizophrenia for } \\
\text { School-Age Children Present and Lifetime } \\
\text { version (K-SADS-PL) [54]. }\end{array}$ & 1997 & $\begin{array}{l}\text { Journal of The American } \\
\text { Academy of Child and } \\
\text { Adolescent Psychiatry }\end{array}$ & Emp & 460 \\
\hline 5 & $\begin{array}{l}\text { Beck, A.T., et al. An Inventory for } \\
\text { Measuring Depression [48]. }\end{array}$ & 1961 & $\begin{array}{l}\text { Archives of General } \\
\text { Psychiatry }\end{array}$ & Con & 452 \\
\hline 6 & $\begin{array}{c}\text { Hankin, B.L., et al. Development of } \\
\text { depression from preadolescence to young } \\
\text { adulthood [55]. }\end{array}$ & 1998 & $\begin{array}{l}\text { Journal of Abnormal } \\
\text { Psychology }\end{array}$ & Emp & 445 \\
\hline 7 & $\begin{array}{l}\text { Baron, R.M., Kenny, D.A. The } \\
\text { moderator-mediator variable distinction } \\
\text { in social psychological research [50]. }\end{array}$ & 1986 & $\begin{array}{l}\text { Journal of Personality and } \\
\text { Social Psychology }\end{array}$ & Con & 443 \\
\hline
\end{tabular}


Table 4. Cont.

\begin{tabular}{|c|c|c|c|c|c|}
\hline Rank & Cited Reference & Year & Source & Paper Type & Co-Citations \\
\hline 8 & $\begin{array}{l}\text { Kovacs, M. The Childrens Depression, } \\
\text { Inventory [30]. }\end{array}$ & 1985 & Psychopharmacology Bulletin & Con & 417 \\
\hline 9 & $\begin{array}{l}\text { Birmaher, B., et al. Childhood and } \\
\text { adolescent depression [17]. }\end{array}$ & 1996 & $\begin{array}{l}\text { Journal of The American } \\
\text { Academy of Child and } \\
\text { Adolescent Psychiatry }\end{array}$ & Rev & 352 \\
\hline 10 & $\begin{array}{l}\text { Kovacs, M. Rating-scales to assess } \\
\text { depression in school-aged children [29]. }\end{array}$ & 1981 & Acta Paedopsychiatrica & Con & 350 \\
\hline 11 & $\begin{array}{l}\text { Hu, L.T., Bentler, P.M. Cutoff criteria for fit } \\
\text { indexes in covariance structure analysis } \\
\text { [51]. }\end{array}$ & 1999 & Structural Equation Modeling & Con & 346 \\
\hline 12 & $\begin{array}{l}\text { Goodman, S.H., Gotlib, I.H. Risk for } \\
\text { psychopathology in the children of } \\
\text { depressed mothers [56]. }\end{array}$ & 1999 & Psychological Review & Con & 345 \\
\hline 13 & $\begin{array}{l}\text { Nolenhoeksema, S., Girgus, J.S. The } \\
\text { Emergence of Gender Differences in } \\
\text { Depression During Adolescence [16]. }\end{array}$ & 1994 & Psychological Bulletin & $\operatorname{Rev}$ & 299 \\
\hline 14 & $\begin{array}{l}\text { Lovejoy, M.C., Graczyk, P.A., O'Hare, E., } \\
\text { Neuman, G. Maternal depression and } \\
\text { parenting behavior [57]. }\end{array}$ & 2000 & Clinical Psychology Review & $\operatorname{Rev}$ & 290 \\
\hline 15 & $\begin{array}{l}\text { Lewinsohn, P.M., Rohde, P., Seeley, J.R., } \\
\text { Fischer, S.A. Age-Cohort Changes in The } \\
\text { Lifetime Occurrence of Depression and } \\
\text { Other Mental-Disorders [58]. }\end{array}$ & 1993 & $\begin{array}{l}\text { Journal of Abnormal } \\
\text { Psychology }\end{array}$ & Emp & 289 \\
\hline 16 & $\begin{array}{l}\text { Downey, G. and Coyne, J.C. Children of } \\
\text { depressed parents [59]. }\end{array}$ & 1990 & Psychological Bulletin & Rev & 287 \\
\hline 17 & $\begin{array}{l}\text { Muthen, L. K., Muthen, B. Mplus User } \\
\text { Guide [53]. }\end{array}$ & 1998 & - & - & 279 \\
\hline 18 & $\begin{array}{l}\text { West, S.G., Hepworth, J.T. Statistical Issues } \\
\text { in The Study of Temporal Data [52]. }\end{array}$ & 1991 & Journal of Personality & Con & 267 \\
\hline 19 & $\begin{array}{l}\text { Cox, J.L., Holden, J.M., Sagovsky, R. } \\
\text { Detection of postnatal depression [60]. }\end{array}$ & 1987 & British Journal of Psychiatry & Con & 263 \\
\hline 20 & $\begin{array}{l}\text { Saylor, C.F., et al. The Childrens } \\
\text { Depression Inventory [32]. }\end{array}$ & 1984 & $\begin{array}{l}\text { Journal of Consulting and } \\
\text { Clinical Psychology }\end{array}$ & Rev & 254 \\
\hline
\end{tabular}

Note. Con = conceptual; Emp = empirical; Rev = review. ${ }^{\text {a }}$ Another two versions of the APA DSM received 429 and 333 co-citations respectively in 2000 and 1987 [61,62].

\subsection{Research Topics}

Keywords reflect the core content of the article, so keyword analysis can help identify important topics in a research field. Keyword co-occurrence analysis is based on the keywords contained in the article, and therefore can provide a more detailed picture of the composition of the knowledge base than co-citation analysis. Like duplicate author processing, keyword co-occurrence analysis must also deal with keywords with the same meaning, like "mother" and "mothers", or "mental-health" and "mental health." The threshold of co-occurrences of a keyword was set to 50, and 257 co-occurring keywords were selected for display.

In the keyword co-occurrence network diagram, common keywords are represented by larger circles and character fonts, and the lines between keywords reflect the correlation between them. As shown in Figure 4, all keywords displayed are grouped into three clusters of different colors. Accordingly, the themes of childhood and adolescent depression research can be divided into the following categories: 


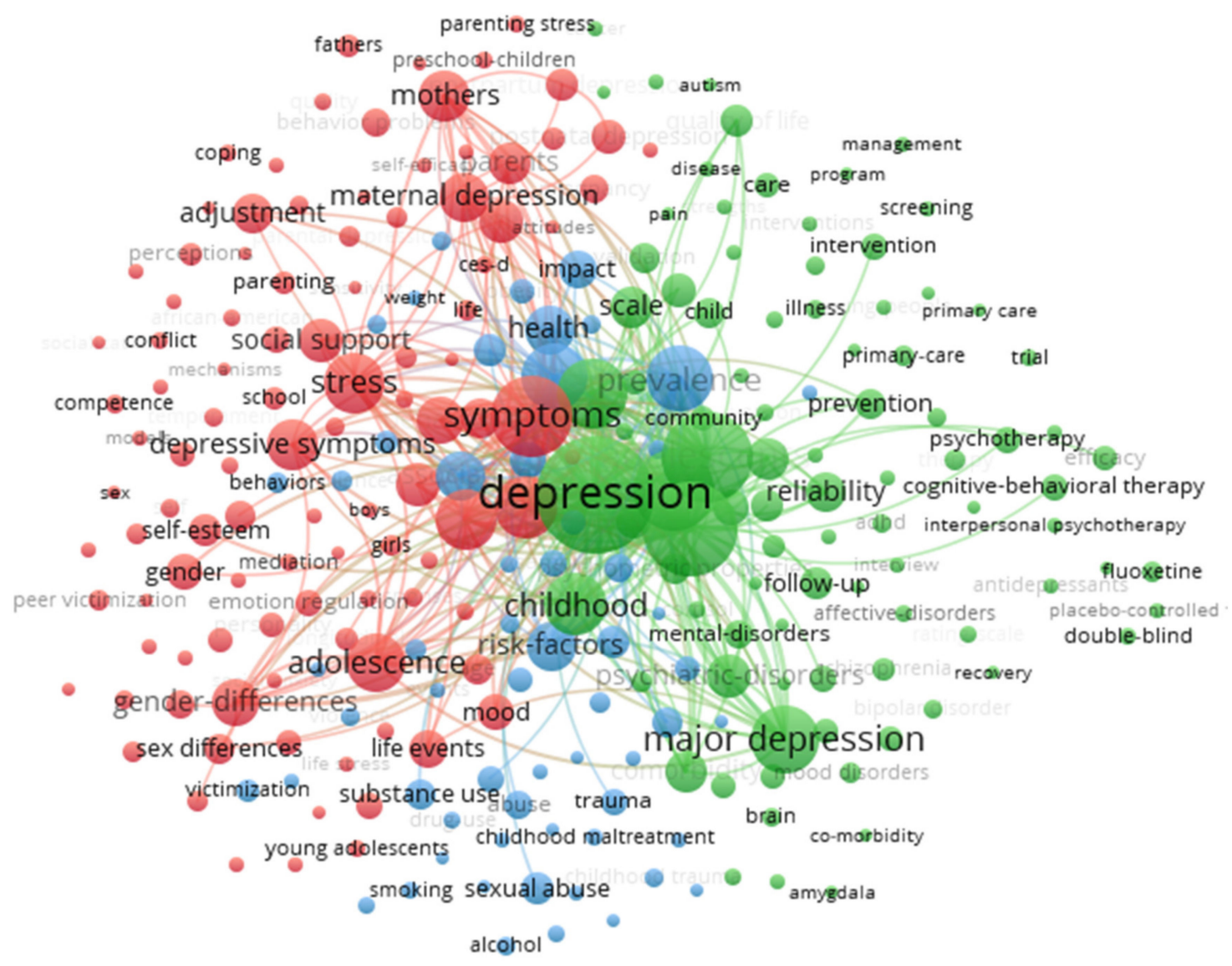

Figure 4. Keyword co-occurrence map from 1970 to 2019 (threshold 50 co-occurrences, display 257 keywords).

(1) Childhood and adolescent depression symptoms and prevalence (green) contains keywords such as "depression", "major depression", "symptoms", "disorder", "anxiety", "children", "prevalence", "comorbidity", "scale", and "inventory". The location of this cluster in the center of the figure emphasizes its status as a cognitive structure in the field of childhood depression. Studies on evaluating the symptoms of depression in children have observed prevalence rates of, for example, 2\% in Iran [63], 3\% in India [64], $4 \%$ in Turkey [65], $4 \%$ in Greece [66], 5\% in America [67], $10 \%$ in Italy [68], and $20 \%$ in China $[69,70]$. Although results may be biased due to differences in sample size and measurement instruments, the consensus among most researchers is that the prevalence of depression is substantial in children and adolescents [71,72]. Some scholars have found that depressive symptoms in children and adolescents are correlated with age, gender, and socioeconomic level [63,73-75]. In addition, some scholars have also explored whether depression symptoms are stable in children; for example, Edelsohn et al. [76] found that reports of depressive symptoms in children were relatively stable during an interval of 4 months. The results of Ialongo [77] and Dubois [78] showed that children's depressive symptoms have much longer-term stability.

Measurement of anxiety and depression among young people has long been a priority in both clinical and research contexts. Accordingly, researchers have developed a number of evaluation instruments to measure depression in children and adolescents. Table 5 outlines the ones most commonly used in scientific literature. Additionally, some researchers have discussed the reliability and validity of different national versions of the child depression scale, such as the Japanese version of the Children's Depression Inventory [79], the German version of the Revised Children's Anxiety and Depression Scale [80], and the Basque version of the Children's Depression Scale [81]. 
Table 5. Summary of the main instruments used in scientific literature.

\begin{tabular}{|c|c|c|}
\hline Name & Simple Description & References \\
\hline $\begin{array}{l}\text { State-Trait Anxiety Inventory for } \\
\text { Children (STAIC) }\end{array}$ & $\begin{array}{l}\text { A widely used instrument of } 20 \text {-item } \\
\text { instrument to measure anxiety } \\
\text { symptoms. }\end{array}$ & Speilberger, 1973 [82] \\
\hline Children's Depression Scale (CDS) & $\begin{array}{c}\text { A commonly used instrument of 66-item } \\
\text { instrument to measure child depression } \\
\text { in psycho-educational and clinical } \\
\text { spheres. }\end{array}$ & Lang and Tisher, 1978 [83] \\
\hline $\begin{array}{l}\text { Children's Depression Rating } \\
\text { Scale-Revised (CDRS-R) }\end{array}$ & $\begin{array}{l}\text { A } 17 \text {-item instrument designed to } \\
\text { measure severity of depression in } \\
\text { children aged } 6 \text { to } 12 \text { years. Total score } \\
\text { ranges from } 17 \text { to } 113.40 \text { or more } \\
\text { presents a major depressive disorder. }\end{array}$ & $\begin{array}{c}\text { Poznanski et al., 1979, 1984, } 1985 \\
{[13,84,85]}\end{array}$ \\
\hline $\begin{array}{l}\text { Peer Nomination Inventory of } \\
\text { Depression (PNID) }\end{array}$ & $\begin{array}{c}\text { A well-developed peer-report instrument } \\
\text { with } 19 \text { items rating depression, } \\
\text { happiness, and popularity }\end{array}$ & Lefkowitz \& Tesiny, 1980 [86] \\
\hline $\begin{array}{l}\text { Center for Epidemiological Studies } \\
\text { Depression Scale for Children (CES-DC) }\end{array}$ & $\begin{array}{l}\text { A 20-item rating scale ranging from } 0 \text { to } 3 \text {, } \\
\text { a general measure of current childhood } \\
\text { psychopathology }\end{array}$ & Weissman et al., 1980 [87] \\
\hline $\begin{array}{l}\text { Depression Self-Rating Scale for Children } \\
\text { (DSRSC) }\end{array}$ & $\begin{array}{l}\text { An 18-item self-report questionnaire used } \\
\text { to measure the depression status of the } \\
\text { children. }\end{array}$ & Birleson, 1981 [88] \\
\hline
\end{tabular}

Child Behavior Checklist (CBCL)

A caregiver-completed and widely utilized questionnaire consists of 20 social competence items and 118 behavior Achenbach \& Edelbrock, 1981 [89] problems items.

Child Behavior Checklist-Teacher Report Form (CBCL-T)
A 120-item standardized teacher rating scale assessing social competence and behavior problems in children and adolescents
Children's Depression Inventory (CDI)

Revised Children's Manifest Anxiety Scale (RCMAS)

Reynolds Adolescent Depression Scale (RADS)

Reynolds Child Depression Scale (RCDS)

Short Mood and Feelings Questionnaire (SMFQ)

Child and Adolescent Psychiatric Assessment (CAPA)

Spence Children's Anxiety Scale (SCAS)
A widely used self-report measure of

27-item measure designed for school-age children and adolescents. Total score ranges from 0 to 54 .
A 37-item self-report measure that provides an estimate of a child's level and degree of experienced anxiety.

A 30-item scale used to assess the severity of depressive symptomatology in adolescent populations.

A 30-item scale designed to assess depressive symptomatology in children $\quad$ Reynolds, 1989 [94] between the ages of 8 and 12 years.

A brief, easy-to-administer, self-report measure of childhood and adolescent

depression

Achenbach \& Edelbrock, 1986 [90]

A semistructured interview designed for use by clinicians or highly trained lay persons to assess 9-to 17-year-olds.

Kovacs, 1985, 1992 [30,91]

Reynolds \& Richmond, 1985 [92]

Reynolds, 1986 [93]

45-item scale with 38 items designed to assess children's report of anxiety

symptoms and 7 items designed to assess social desirability. 
Table 5. Cont.

\begin{tabular}{|c|c|c|}
\hline Name & Simple Description & References \\
\hline $\begin{array}{l}\text { Schedule for Affective Disorders and } \\
\text { Schizophrenia for School-age } \\
\text { Children-Present and Lifetime version } \\
\text { (K-SADS-PL) }\end{array}$ & $\begin{array}{c}\text { An interviewer-based schedule designed } \\
\text { for assessing and diagnosing episodes of } \\
\text { psychopathology in youngsters. }\end{array}$ & Kaufman et al., 1997 [54] \\
\hline $\begin{array}{l}\text { Positive and Negative Affect Schedule for } \\
\text { Children (PANAS-C) }\end{array}$ & $\begin{array}{l}\text { A 20-item self-report measure consisting } \\
\text { of two scales: Positive Affect (PA) and } \\
\text { Negative Affect (NA). }\end{array}$ & Crook et al., 1998 [98] \\
\hline $\begin{array}{c}\text { Diagnostic Interview for Children and } \\
\text { Adolescents (DICA) }\end{array}$ & $\begin{array}{l}\text { A respondent-based interview schedule } \\
\text { for youngsters aged } 6 \text { to } 17 \text { years that can } \\
\text { be administered either by clinicians or by } \\
\text { lay interviewers. }\end{array}$ & Reich, 2000 [99] \\
\hline $\begin{array}{l}\text { Diagnostic Interview Schedule for } \\
\text { Children (DISC-IV) }\end{array}$ & $\begin{array}{c}\text { An instrument designed to address more } \\
\text { than } 30 \text { psychiatric diagnoses that occur } \\
\text { in children and adolescents }\end{array}$ & Shaffer et al., 2000 [100] \\
\hline $\begin{array}{l}\text { Revised Child Anxiety and Depression } \\
\text { Scales (RCADS) }\end{array}$ & $\begin{array}{c}\text { A 47-item self-report questionnaire } \\
\text { designed to assess for clinical syndromes } \\
\text { in youth. }\end{array}$ & Chorpita et al., 2000 [35] \\
\hline $\begin{array}{l}\text { Kutcher Adolescent Depression Scale } \\
\text { (KADS) }\end{array}$ & $\begin{array}{l}\text { An 11-item, self-report instrument } \\
\text { designed to aid in diagnosis and } \\
\text { monitoring the change in the severity of } \\
\text { symptoms during the course of } \\
\text { treatment. }\end{array}$ & Brooks \& Kutcher, 2001 [101] \\
\hline Children's Thought Questionnaire (CTQ) & $\begin{array}{l}\text { A } 60 \text {-item scale designed to assess } \\
\text { children's self-reported anxious, } \\
\text { depressive, and positive thoughts. }\end{array}$ & Marien and Bell, 2004 [102] \\
\hline $\begin{array}{c}\text { Dysfunctional Attitudes Scale for } \\
\text { Children (DAS-C) }\end{array}$ & $\begin{array}{l}\text { A 22-item self-report measure with sound } \\
\text { psychometric properties. }\end{array}$ & D'Alessandro and Burton, 2006 [103] \\
\hline
\end{tabular}

(2) Parental depression and child behavioral or emotional problems (red) covers "mothers", "maternal depression", "parents", "fathers", "family", "parental depression", "parenting stress", "caregivers", "pregnancy", and "postnatal depression". One set of themes relates to parental depression and child mental health and behavioral problems.

Associations between parental depression and child affective and destructive disorders have been fully demonstrated [104]. Research has shown that children with parents suffering from major depression (MDD) are 4-6 times more likely to develop MDD than other children [105]. However, scholars have not reached a consensus on the extent to which parental depression affects depression in children. Some studies have highlighted that maternal mental illness is a potential risk factor for childhood psychiatric disorders [106], while paternal depression is not associated with an increased risk of adolescent psychopathology [107]. However, the findings of some scholars indicate that the negative interpersonal relationship effects of parental depression on child psychopathology may not be limited to mothers $[108,109]$. They emphasized that fathers may play a role in reducing or exacerbating the long-term adverse effects of maternal depression on child behavior problems [110]. Studies have shown that children with depressed mothers exhibit more behavioral problems than children whose mothers are not depressed [111] and that maternal depression is negatively associated with social competence in children and positively associated with behavioral problems [112]. Additionally, some studies have explored the association between maternal depression and children's outcomes in terms of economic resources, maternal parenting behavior, family environment and genetic factors $[113,114]$.

Another aspect of this cluster mainly concerns the negative impact of postpartum depression on child development and well-being $[115,116]$. There have been some interesting studies; for example, depression in fathers in the postnatal period is associated with 
later psychiatric disorders in their children, independently of maternal postnatal depression [117]. Another example is that female fetuses are more susceptible to the mother's stress responses during pregnancy, which continues into adolescence [118]. All of these aspects could be important for future public health interventions.

(3) Childhood abuse and depression (blue) are represented by keywords like "sexual abuse", "abuse", "maltreatment", "experiences", "child abuse", "childhood trauma", "physical abuse", and "stressful life events". Childhood trauma (CT) is very common and may have long-term consequences for physical and mental health, especially depression $[119,120]$. Studies in this cluster have shown that: (1) A history of childhood abuse and neglect can exacerbate the psychosocial dysfunction associated with depression [121], and even induce new or recurring depressive episodes [122]; meanwhile, childhood maltreatment not only increases lifetime risk of depression, but also has a negative impact on clinically relevant measures of depression. Therefore, early recognition of childhood abuse and appropriate intervention can play an important role in preventing depression [37,40]. (2) Taking age and gender into account, existing findings suggest that the effects of childhood maltreatment on depression may increase with age, and that the effects at different developmental stages may lead to distinct psychiatric symptoms in adulthood [123]. Some research has shown that the association between childhood abuse and depression is most important for women, while other studies have found that men and women who report a history of childhood abuse are equally likely to suffer from severe depression in adulthood [124,125]. (3) Existing research has investigated possible moderating or mediating effects on the association between childhood maltreatment and depressive and anxiety disorders such as emotion dysregulation [126,127], as well as resilience [128,129], personality traits [130-133], maternal relationship quality and peer social acceptance [134], feelings of shame [135], perceived friendship (social support from family and friends) [136], rumination [137], self-compassion and gratitude [138] and adult negative life events [139].

Keywords can also serve as indicators to reflect the changes of research hotspots over time, which can help researchers predict the "research front" of a knowledge base and quickly discover the latest topical trends in the literature. The VOSviewer can apply colors to keywords based on when they appear in the journal. As shown in Figure 5, the yellow nodes in the figure represent the topics more recently highlighted in the literature.

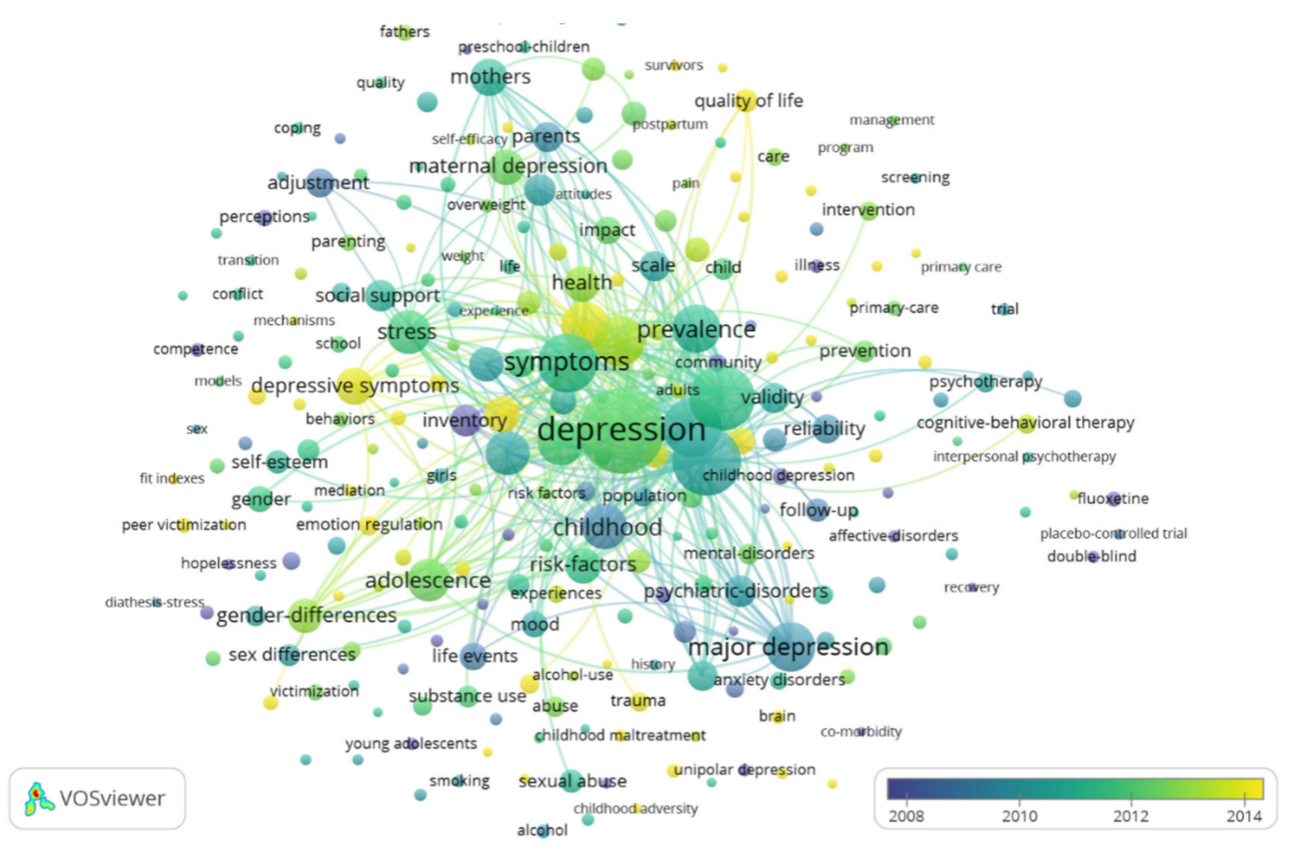

Figure 5. Distribution of keywords based on the time of appearance. Keywords are marked by circles in different colors (blue early; yellow later; threshold 50 co-occurrences, display 257 keywords). 
Childhood trauma, abuse, and other adverse experiences are important early social risk factors for the development of depression. Yet, the pathway through which exposure to adverse childhood experiences affects the prevalence and severity of depressive symptoms remains largely unclear. Recently, scholars have studied the relationship between adverse childhood experiences and depression, especially in terms of the mediating or moderating effects of resilience or emotion regulation. These relatively new studies have yielded some useful results. For example, children high in emotion dysregulation may be at increased risk for depression $[140,141]$. They underscored the importance of assessing emotion regulation abilities in abused youth and noted that interventions targeting emotional regulation strategies may help reduce depression among children suffering from adversity [142,143]. They also found that resilience may play an important role in the relationship between adverse childhood experiences and depressive symptoms, so improving resilience may offer a new possibility for preventing adolescent depression [128].

\section{Discussion and Conclusions}

The amount of literature on childhood and adolescent depression has become substantial since its beginnings in the 1970s. The significant increase in the number of documents allows us to see scholars' increasing attention and continuous thinking about childhood and adolescent depression. Our topographical analysis of the literature found a skewed geographical distribution with a majority of the literature coming from the United States, England, Canada, Australia, and Netherlands. Fortunately, this imbalance has eased over the past decade. In particular, we have seen an increasing proportion of papers being produced by scholars in Asia and Latin America. Nevertheless, as shown in Figure 2, there are still many 'blank areas' on the world map, representing that there is little or no research and practice on childhood and adolescent depression in these areas. Most of these blank spots are in African countries, which means that the study of child depression in these areas is urgent. Therefore, we advocate for greater geographic diversity in the sources of literature on childhood and adolescent depression.

The citation analysis in Tables 3 and 4 highlights the important role of bibliometrics in the analysis of the development of knowledge in a particular area. Judging from the results of this article, it is feasible to trace the evolution of childhood and adolescent depression research through citation analysis and co-citation analysis. It is worth noting that these articles not only include literature centered on childhood and adolescent depression $[15,17,29,30,56,91]$ but also related articles that provide a conceptual basis for the knowledge base for childhood and adolescent depression [48-50]. We assert that the identification of these knowledge bases through co-citation analysis is not only a recognition of scientific mapping methods, but also high-quality scholarship.

Another contribution of this paper lies in the empirical identification of research topics about childhood and adolescent depression relying on keyword co-occurrence analysis. These topics basically summarize three major aspects of childhood and adolescent depression research, including child and adolescent depression symptoms and prevalence, parental depression and child behavioral or emotional problems, and childhood abuse and depression. Although many diagnostic instruments for depression have been developed and validated by researchers, some of the instruments used in existing studies have demonstrated certain weaknesses in their validity or reliability. Therefore, a simple, manageable, effective, and reliable instrument that can diagnose and measure the severity of symptoms of depression in children and adolescents is needed in the future. The prevention of depression is a focus of the World Health Organization [144]. However, current depression prevention programs are mainly targeted at adolescents, and little attention is paid to children under 10 years old. Meanwhile, depression treatment is also important. The World Health Organization and the World Bank claimed in 2016 that the annual cost of depression and other similar diseases to the global economy had reached one trillion US dollars. A series of studies on this subject has also been carried out recently. Researchers are eager to find tools or preventative intervention strategies that can reduce or alleviate childhood and 
adolescent depression. This study has found that the two keywords "emotion regulation" and "resilience" have become research frontiers in recent years. Therefore, future research should be carried out in these areas. Furthermore, earlier identification and treatment, attention to the need for treatment of parental depression, and the development of new therapeutics for adolescents who do not have a response to current treatments would be beneficial.

The future research potential of sanitation may be informed by our analysis. First, as the global average temperature has risen, climate warming has caused a series of impacts on human health. Many studies focus on the relationship between temperature and people's mental health, but most of these studies focus on the general population or the elderly [145-147], and there is a lack of relevant studies on children and adolescents. Secondly, breakthroughs in research methods and analytical frameworks can be sought. In terms of research methodology, innovative methods such as machine learning and big data mining can be used in depression research. In view of the continuous optimization of machine learning algorithms and the increasing information available from big data, the application of machine learning to modeling, especially the establishment of interdisciplinary models, will provide important ideas for depression research in children and adolescents.

Author Contributions: Conceptualization, M.Z. and L.H.; methodology, L.H.; software, L.H. and B.B.; formal analysis, L.H., B.B. and W.Z.; data curation, L.H., B.B. and W.Z.; writing-original draft preparation, L.H.; writing-review and editing, M.Z. All authors have read and agreed to the published version of the manuscript.

Funding: We would like to acknowledge the support of the National Natural Science Foundation of China (Grants No. 71903133, 71973100), the Liaoning Province Xingliao Talents Plan Project (Grant No. XLYC2007138).

Institutional Review Board Statement: Not applicable.

Informed Consent Statement: Not applicable.

Data Availability Statement: Publicly available datasets were analyzed in this study. This data can be found here: [http://webofscience.com].

Conflicts of Interest: The authors declare no conflict of interest.

\section{References}

1. Thapar, A.; Collishaw, S.; Pine, D.S.; Thapar, A.K. Depression in adolescence. Lancet 2012, 379, 1056-1067. [CrossRef]

2. Thapar, A.; Collishaw, S.; Potter, R.; Thapar, A.K. Managing and preventing depression in adolescents. BMJ 2010, 340, c209. [CrossRef] [PubMed]

3. Lewinsohn, P.M.; Pettit, J.W.; Joiner, T.E.; Seeley, J.R. The symptomatic expression of major depressive disorder in adolescents and young adults. J. Abnorm. Psychol. 2003, 112, 244-252. [CrossRef] [PubMed]

4. Schumacher, H.C. The depression and its effect on the mental health of the child. Am. J. Public Health Nations Health 1934, 24, 367-371. [CrossRef] [PubMed]

5. Friedman, R.J.; Doyal, G.T. Depression in children-Some observations for school psychologist. Psychol. Sch. 1974, 11, 19-23.

6. Connell, H.M. Depression in Childhood. Child Psychiatry Hum. Dev. 1973, 4, 71-85. [CrossRef] [PubMed]

7. Poznanski, E.O.; Krahenbuhl, V.; Zrull, J.P. Childhood depression-Longitudinal perspective. J. Am. Acad. Child Adolesc. Psychiatry 1976, 15, 491-501. [CrossRef]

8. Poznanski, E.O.; Zrull, J.P. Childhood depression-clinical characteristics of overtly depressed children. Arch. Gen. Psychiatry 1970, 23, 8-15. [CrossRef]

9. Cytryn, L.; Mcknew, D.H. Proposed classification of childhood depression. Am. J. Psychiatry 1972, 129, 149-155. [CrossRef]

10. Mcconville, B.J.; Boag, L.C.; Purohit, A.P. 3 types of childhood depression. Can. Psychiatr. Assoc. J. 1973, 18, 133-138. [CrossRef]

11. Pearce, J.B. Recognition of depressive disorder in children. J. R. Soc. Med. 1978, 71, 494-500. [CrossRef]

12. Petti, T.A. Depression in hospitalized child-psychiatry patients-approaches to measuring depression. J. Am. Acad. Child. Adolesc. Psychiatry 1978, 17, 5-49. [CrossRef]

13. Poznanski, E.O.; Cook, S.C.; Carroll, B.J. Depression rating-scale for children. Pediatrics 1979, 64, 442-450. [CrossRef]

14. Cantwell, D.P.; Carlson, G. Problems and prospects in the study of childhood depression. J. Nerv. Ment. Dis. 1979, 16, 522-529. [CrossRef]

15. Goodman, S.H.; Rouse, M.H.; Connell, A.M.; Broth, M.R.; Hall, C.M.; Heyward, D. Maternal depression and child psychopathology: A meta-analytic review. Clin. Child. Fam. Psychol. Rev. 2011, 14, 1-27. [CrossRef] 
16. Nolenhoeksema, S.; Girgus, J.S. The Emergence of Gender Differences in Depression during Adolescence. Psychol. Bull. 1994, 115, 424-443. [CrossRef]

17. Birmaher, B.; Ryan, N.D.; Williamson, D.E.; Brent, D.A.; Kaufman, J.; Dahl, R.E.; Perel, J.; Nelson, B. Childhood and adolescent depression: A review of the past 10 years. J. Am. Acad. Child. Adolesc. Psychiatry 1996, 35, 1427-1439. [CrossRef]

18. Weisz, J.R.; McCarty, C.A.; Valeri, S.M. Effects of psychotherapy for depression in children and adolescents: A meta-analysis Psychol. Bull. 2006, 132, 132-149. [CrossRef] [PubMed]

19. Wang, Z.H.; Zhao, Y.D.; Wang, B. A bibliometric analysis of climate change adaptation based on massive research literature data. J. Clean Prod. 2018, 199, 1072-1082. [CrossRef]

20. Hallinger, P.; Kovacevic, J. A Bibliometric Review of Research on Educational Administration: Science Mapping the Literature, 1960 to 2018. Rev. Educ. Res. 2019, 89, 335-369. [CrossRef]

21. Shiffrin, R.M.; Börner, K. Mapping knowledge domains. Proc. Natl. Acad. Sci. USA 2004, 101, 5183-5185. [CrossRef]

22. Chen, Y.; Liu, Z.Y.; Chen, J.; Hou, J.H. History and theory of mapping knowledge domains. Stud. Sci. Sci. 2008, 26, 449-460. (In Chinese)

23. Zupic, I.; Čater, T. Bibliometric methods in management and organization. Organ. Res. Methods 2015, 18, 429-472. [CrossRef]

24. Small, H. Co-citation in the scientific literature: A new measure of the relationship between two documents. J. Am. Soc. Inf. Sci. 1973, 24, 265-269. [CrossRef]

25. Merton, R.K. The Sociology of Science: Theoretical and Empirical Investigations; University of Chicago Press: Chicago, IL, USA, 1973.

26. Gilbert, G.N. Referencing as persuasion. Soc. Stud. Sci. 1977, 7, 113-122. [CrossRef]

27. Goncalves, M.C.P.; Kieckbusch, T.G.; Perna, R.F.; Fujimoto, J.T.; Morales, S.A.V.; Romanelli, J.P. Trends on enzyme immobilization researches based on bibliometric analysis. Process. Biochem. 2019, 76, 95-110. [CrossRef]

28. Strotmann, A.; Zhao, D.Z. Author name disambiguation: What difference does it make in author-based citation analysis? J. Am. Soc. Inf. Sci. Technol. 2012, 63, 1820-1833. [CrossRef]

29. Kovacs, M. Rating-scales to assess depression in school-aged children. Acta Paedopsychiatr. 1981, 46, 305-315. [PubMed]

30. Kovacs, M. The Children's Depression, Inventory (CDI). Psychol. Bull. 1985, 21, 995-998.

31. Radloff, L.S. The Use of The Center for Epidemiologic Studies Depression Scale in Adolescents and Young-Adults. J. Youth Adolesc. 1991, 20, 149-166. [CrossRef]

32. Saylor, C.F.; Finch, A.J.; Spirito, A.; Bennett, B. The Children's depression inventory-A systematic evaluation of psychometric properties. J. Consult. Clin. Psychol. 1984, 52, 955-967. [CrossRef]

33. Smucker, M.R.; Craighead, W.E.; Craighead, L.W.; Green, B.J. Normative and reliability data for the children's depression inventory. J. Abnorm. Child. Psychol. 1986, 14, 25-39. [CrossRef]

34. Angold, A.; Costello, E.J.; Messer, S.C.; Pickles, A.; Winder, F.; Silver, D. Development of a short questionnaire for use in epidemiological studies of depression in children and adolescents. Int. J. Methods. Psychiatr. Res. 1995, 5, $237-249$.

35. Chorpita, B.F.; Yim, L.; Moffitt, C.E.; Umemoto, L.A.; Francis, S.E. Assessment of symptoms of DSM-IV anxiety and depression in children: A revised child anxiety and depression scale. Behav. Res. Ther. 2000, 38, 835-855. [CrossRef]

36. Twenge, J.M.; Nolen-Hoeksema, S. Age, gender, race, socioeconomic status, and birth cohort differences on the Children's Depression Inventory: A meta-analysis. J. Abnorm. Psychol. 2002, 111, 578-588. [CrossRef]

37. Chapman, D.P.; Whitfield, C.L.; Felitti, V.J.; Dube, S.R.; Edwards, V.J.; Anda, R.F. Adverse childhood experiences and the risk of depressive disorders in adulthood. J. Affect. Disord. 2004, 82, 217-225. [CrossRef]

38. Widom, C.S.; DuMont, K.; Czaja, S.J. A prospective investigation of major depressive disorder and comorbidity in abused and neglected children grown up. Arch. Gen. Psychiatry. 2007, 64, 49-56. [CrossRef]

39. Danese, A.; Moffitt, T.E.; Harrington, H.; Milne, B.J.; Polanczyk, G.; Pariante, C.M.; Poulton, R.; Caspi, A. Adverse childhood experiences and adult risk factors for age-related disease depression, inflammation, and clustering of metabolic risk markers. Arch. Pediatr. Adolesc. Med. 2009, 163, 1135-1143. [CrossRef]

40. Nanni, V.; Uher, R.; Danese, A. Childhood maltreatment predicts unfavorable course of illness and treatment outcome in depression: A meta-analysis. Am. J. Psychiatry. 2012, 169, 141-151. [CrossRef] [PubMed]

41. Lewinsohn, P.M.; Hops, H.; Roberts, R.E.; Seeley, J.R.; Andrews, J.A. Adolescent Psychopathology. 1. Prevalence and Incidence of Depression and Other DSM-III-R Disorders in High-School-Students. J. Abnorm. Psychol. 1993, 102, 133-144. [CrossRef] [PubMed]

42. Pine, D.S.; Cohen, P.; Gurley, D.; Brook, J. The risk for early-adulthood anxiety and depressive disorders in adolescents with anxiety and depressive disorders. Arch. Gen. Psychiatry 1998, 55, 56-64. [CrossRef] [PubMed]

43. Cyranowski, J.M.; Frank, E.; Young, E.; Shear, M.K. Adolescent onset of the gender difference in lifetime rates of major depressionA theoretical model. Arch. Gen. Psychiatry 2000, 57, 21-27. [CrossRef]

44. Emslie, G.J.; Rush, A.J.; Weinberg, W.A.; Kowatch, R.A.; Hughes, C.W.; Carmody, T.; Rintelmann, J. A double-blind, randomized, placebo-controlled trial of fluoxetine in children and adolescents with depression. Arch. Gen. Psychiatry 1997, 54, 1031-1037. [CrossRef]

45. Whittington, C.J.; Kendall, T.; Fonagy, P.; Cottrell, D.; Cotgrove, A.; Boddington, E. Selective serotonin reuptake inhibitors in childhood depression: Systematic review of published versus unpublished data. Lancet 2004, 363, 1341-1345. [CrossRef]

46. Kovacs, M.; Feinberg, T.L.; Crousenovak, M.A.; Paulauskas, S.L.; Finkelstein, R. Depressive-disorders in childhood.1. a longitudinal prospective-study of characteristics and recovery. Arch. Gen. Psychiatry 1984, 41, 229-237. [CrossRef] 
47. Costello, E.J.; Erkanli, A.; Angold, A. Is there an epidemic of child or adolescent depression? J. Child. Psychol. Psychiatry 2006, 47, 1263-1271. [CrossRef]

48. Beck, A.T.; Erbaugh, J.; Ward, C.H.; Mock, J.; Mendelsohn, M. An inventory for measuring depression. Arch. Gen. Psychiatry 1961, 4, 561-571. [CrossRef]

49. Radloff, L.S. The CES-D Scale: A self-report depression scale for research in the general population. Appl. Psychol. Meas. 1977, 1, 385-401. [CrossRef]

50. Baron, R.M.; Kenny, D.A. The moderator-mediator variable distinction in social psychological research: Conceptual, strategic, and statistical considerations. J. Pers. Soc. Psychol. 1986, 51, 1173-1182. [CrossRef] [PubMed]

51. Hu, L.T.; Bentler, P.M. Cutoff criteria for fit indexes in covariance structure analysis: Conventional criteria versus new alternatives. Struct. Equ. Modeling 1999, 6, 1-55. [CrossRef]

52. West, S.G.; Hepworth, J.T. Statistical Issues in The Study of Temporal Data. J. Pers. 1991, 59, 609-662. [CrossRef]

53. Kovacs, M.; Goldston, D.; Obrosky, D.S. Prevalence and predictors of pervasive noncompliance with medical-treatment among youths with insulin-dependent diabetes-mellitus. J. Am. Acad. Child. Adolesc. Psychiatry 1992, 31, 1112-1119. [CrossRef] [PubMed]

54. Kaufman, J.; Birmaher, B.; Brent, D.; Rao, U.M.A.; Flynn, C.; Moreci, P.; Williamson, D.; Ryan, N. Schedule for affective disorders and schizophrenia for school-age children present and lifetime version (K-SADS-PL): Initial reliability and validity data. J. Am. Acad. Child. Adolesc. Psychiatry 1997, 36, 980-988. [CrossRef] [PubMed]

55. Hankin, B.L.; Abramson, L.Y.; Moffitt, T.E.; Silva, P.A.; McGee, R.; Angell, K.E. Development of depression from preadolescence to young adulthood: Emerging gender differences in a 10-year longitudinal study. J. Abnorm. Psychol. 1998, 107, 128-140. [CrossRef] [PubMed]

56. Goodman, S.H.; Gotlib, I.H. Risk for psychopathology in the children of depressed mothers: A developmental model for understanding mechanisms of transmission. Psychol. Rev. 1999, 106, 458-490. [CrossRef] [PubMed]

57. Lovejoy, M.C.; Graczyk, P.A.; O’Hare, E.; Neuman, G. Maternal depression and parenting behavior: A meta-analytic review. Clin. Psychol. Rev. 2000, 20, 561-592. [CrossRef]

58. Lewinsohn, P.M.; Rohde, P.; Seeley, J.R.; Fischer, S.A. Age-Cohort Changes in The Lifetime Occurrence of Depression and Other Mental-Disorders. J. Abnorm. Psychol. 1993, 102, 110-120. [CrossRef]

59. Downey, G.; Coyne, J.C. Children of depressed parents: An integrative review. Psychol. Bull. 1990, 108, 50-76. [CrossRef] [PubMed]

60. Cox, J.L.; Holden, J.M.; Sagovsky, R. Detection of postnatal depression: Development of the 10-item Edinburgh Postnatal Depression Scale. Br. J. Psychiatry 1987, 150, 782-786. [CrossRef] [PubMed]

61. American Psychiatric Association (APA). Diagnostic and Statistical Manual of Mental Disorders, 4th ed.; Revised; American Psychiatric Association: Washington, DC, USA, 2000.

62. American Psychiatric Association (APA). Diagnostic and Statistical Manual of Mental Disorders, 3rd ed.; Revised; American Psychiatric Association: Washington, DC, USA, 1987.

63. Mohammadi, M.R.; Alavi, S.S.; Ahmadi, N.; Khaleghi, A.; Kamali, K. The prevalence, comorbidity and socio-demographic factors of depressive disorder among Iranian children and adolescents: To identify the main predictors of depression. J. Affect. Disord. 2019, 247, 1-10. [CrossRef]

64. Sarkar, S.; Sinha, V.K.; Praharaj, S.K. Depressive disorders in school children of suburban India: An epidemiological study. Soc. Psychiatry Psychiatr. Epidemiol. 2012, 47, 783-788. [CrossRef] [PubMed]

65. Demir, T.; Karacetin, G.; Demir, D.E.; Uysal, O. Epidemiology of depression in an urban population of Turkish children and adolescents. J. Affect. Disord. 2011, 134, 168-176. [CrossRef]

66. Giannakopoulos, G.; Kazantzi, M.; Dimitrakaki, C.; Tsiantis, J.; Kolaitis, G.; Tountas, Y. Screening for children's depression symptoms in Greece: The use of the Children's Depression Inventory in a nation-wide school-based sample. Eur. Child. Adolesc. Psychiatry 2009, 18, 485-492. [CrossRef]

67. Bitsko, R.H.; Holbrook, J.R.; Ghandour, R.M.; Blumberg, S.J.; Visser, S.N. Epidemiology and impact of health care providerdiagnosed anxiety and depression among US children. J. Dev. Behav. Pediatr. 2018, 39, 395-403. [CrossRef] [PubMed]

68. Frigerio, A.; Pesenti, S.; Molteni, M.; Snider, J.; Battaglia, M. Depressive symptoms as measured by the CDI in a population of northern Italian children. Eur. Psychiatry 2001, 16, 33-37. [CrossRef]

69. Wang, L.; Feng, Z.; Yang, G.; Yang, Y.; Wang, K.; Dai, Q.; Zhao, M.; Hu, C.; Zhang, R.; Liu, K.; et al. Depressive symptoms among children and adolescents in western china: An epidemiological survey of prevalence and correlates. Psychiat. Res. 2016, 246, 267-274. [CrossRef] [PubMed]

70. Zhou, M.; Zhang, G.; Rozelle, S.; Kenny, K.; Xue, H. Depressive symptoms of Chinese children: Prevalence and correlated factors among subgroups. Int. J. Envl. Res. Pub. He. 2018, 15, 283. [CrossRef] [PubMed]

71. Akimana, B.; Abbo, C.; Balagadde-Kambugu, J.; Nakimuli-Mpungu, E. Prevalence and factors associated with major depressive disorder in children and adolescents at the Uganda Cancer Institute. BMC Cancer 2019, 19, 466. [CrossRef]

72. Sorensen, M.J.; Nissen, J.B.; Mors, O.; Thomsen, P.H. Age and gender differences in depressive symptomatology and comorbidity: An incident sample of psychiatrically admitted children. J. Affect. Disord. 2005, 84, 85-91. [CrossRef]

73. Jaureguizar, J.; Bernaras, E.; Garaigordobil, M. Child Depression: Prevalence and comparison between self-reports and teacher reports. Span. J. Psychol. 2017, 20, e17. [CrossRef] 
74. Shooshtari, S.; Brownell, M.; Dik, N.; Chateau, D.; Yu, C.T. A population-based longitudinal study of depression in children with developmental disabilities in Manitoba. J. Ment. Health Res. Intellect. Disabil. 2014, 7, 191-207. [CrossRef]

75. Pereira, T.S.; Silva, A.A.; Alves, M.T.; Simões, V.M.; Batista, R.F.; Rodriguez, J.D.; Figueiredo, F.P.; Lamy-Filho, F.; Barbieri, M.A.; Bettiol, H. Perinatal and early life factors associated with symptoms of depression in Brazilian children. BMC Public Health 2012, 12, 605. [CrossRef] [PubMed]

76. Edelsohn, G.; Ialongo, N.; Werthamer-Larsson, L.; Crockett, L.; Kellam, S. Self-reported depressive symptoms in first-grade children: Developmentally transient phenomena? J. Am. Acad. Child. Adolesc. Psychiatry 1992, 31, 282-290. [CrossRef]

77. Ialongo, N.; Edelsohn, G.; Werthamerlarsson, L.; Crockett, L.; Kellam, S. Are self-reported depressive symptoms in 1st-grade children developmentally transient phenomena-a further look. Dev. Psychopathol. 1993, 5, 433-457. [CrossRef]

78. Dubois, D.L.; Felner, R.D.; Bartels, C.L.; Silverman, M.M. Stability of self-reported depressive symptoms in a community sample of children and adolescents. J. Clin. Child. Psychol. 1995, 24, 386-396. [CrossRef]

79. Ozono, S.; Nagamitsu, S.; Matsuishi, T.; Yamashita, Y.; Ogata, A.; Suzuki, S.; Mashida, N.; Koseki, S.; Sato, H.; Ishikawa, S.; et al. Reliability and validity of the children's depression inventory-Japanese version. Pediatr. Int. 2019, 61, 1159-1167. [CrossRef]

80. Stahlschmidt, L.; Chorpita, B.F.; Wager, J. Validating the German version of the revised children's anxiety and depression scale in a sample of pediatric chronic pain patients. J. Psychosom. Res. 2019, 124, 109786. [CrossRef]

81. Balluerka, N.; Gorostiaga, A.; Haranburu, M. Validation of children's depression scale in the basque-speaking population. Span. J. Psychol. 2012, 15, 1400-1410. [CrossRef]

82. Speilberger, C.D. Manual for the State-Trait Anxiety Inventory for Children; Consulting Psychologists Press: Palo Alto, CA, USA, 1973.

83. Lang, M.; Tisher, M. Children's Depression Scale; Australian Council for Educational Research: Camberwell, Australia, 1978.

84. Poznanski, E.O.; Grossman, J.A.; Buchsbaum, Y.; Banegas, M.; Freeman, L.; Gibbons, R. Preliminary studies of the reliability and validity of the children's depression rating-scale. J. Am. Acad. Child Adolesc. Psychiatry 1984, 23, 191-197.

85. Poznanski, E.O.; Freeman, L.N.; Mokros, H.B. Children's depression rating scale-revised. Psychopharmacol. Bull. 1985, 21, 979-989.

86. Lefkowitz, M.M.; Tesiny, E.P. Assessment of childhood depression. J. Consult. Clin. Psychol. 1980, 48, 43-50. [CrossRef] [PubMed]

87. Weissman, M.M.; Orvaschel, H.; Padian, N. Children's symptom and social functioning self- report scales: Comparison of mothers' and children's reports. J. Nerv. Ment. Dis. 1980, 168, 736-740. [CrossRef] [PubMed]

88. Birleson, P. The validity of depressive disorder in childhood and the development of a self-rating scale: A research report. J. Child. Psychol. Psychiatry 1981, 22, 73-88. [CrossRef]

89. Achenbach, T.M.; Edelbrock, C.S. Behavioral-problems and competencies reported by parents of normal and disturbed-children aged 4 through 16. Monogr. Soc. Res. Child. Dev. 1981, 46, 1-82. [CrossRef] [PubMed]

90. Achenbach, T.M.; Edelbrock, C.S. Manual for the Teachers Report form and the Teacher Version of the Child Behavior Profile; University of Vermont, Department of Psychiatry: Burlington, VT, USA, 1986.

91. Kovacs, M. Children's Depression Inventory Manual; Western Psychological Services: Los Angeles, CA, USA, 1992.

92. Reynolds, C.R.; Richmond, B.O. Revised Children's Manifest Anxiety Scale; Western Psychological Services: Los Angeles, CA, USA, 1985.

93. Reynolds, W.M. Reynolds Adolescent Depression Scale; Psychological Assessment Resources: Odessa, FL, USA, 1986.

94. Reynolds, W.M. Reynolds Child. Depression Scale. Professional Manual; Psychological Assessment Resources: Odessa, FL, USA, 1989.

95. Angold, A.; Prendergast, M.; Cox, A.; Harrington, R.; Simonoff, E.; Rutter, M. The Child and adolescent psychiatric-assessment (CAPA). Psychol. Med. 1995, 25, 739-753. [CrossRef]

96. Angold, A.; Costello, E.J. The child and adolescent psychiatric assessment (CAPA). J. Am. Acad. Child. Adolesc. Psychiatry 2000, 39, 39-48. [CrossRef] [PubMed]

97. Spence, S.H. Structure of anxiety symptoms among children: A confirmatory factor-analytic study. J. Abnorm. Psychol. 1997, 106, 280-297. [CrossRef] [PubMed]

98. Crook, K.; Beaver, B.R.; Bell, M. Anxiety and depression in children: A preliminary examination of the utility of the PANAS-C. J. Psychopathol. Behav. Assess. 1998, 20, 333-350. [CrossRef]

99. Reich, W. Diagnostic Interview for Children and Adolescents (DICA). J. Am. Acad. Child. Adolesc. Psychiatry 2000, 39, 59-66. [CrossRef]

100. Shaffer, D.; Fisher, P.; Lucas, C.P.; Dulcan, M.K.; Schwab-Stone, M.E. NIMH Diagnostic Interview Schedule for Children Version IV (NIMH DISC-IV): Description, differences from previous versions, and reliability of some common diagnoses. J. Am. Acad. Child. Adolesc. Psychiatry 2000, 39, 28-38. [CrossRef]

101. Brooks, S.J.; Kutcher, S. Diagnosis and measurement of adolescent depression: A review of commonly utilized instruments. J. Child. Adolesc. Psychopharmacol. 2001, 11,341-376. [CrossRef]

102. Marien, W.E.; Bell, D.J. Anxiety- and depression-related thoughts in children: Development and evaluation of a cognition measure. J. Clin. Child. Adolesc. Psychol. 2004, 33, 717-730. [CrossRef]

103. D'Alessandro, D.U.; Burton, K.D. Development and validation of the dysfunctional attitudes scale for children: Tests of beck's cognitive diathesis-stress theory of depression, of its causal mediation component, and of developmental effects. Cognit. Ther. Res. 2006, 30, 335-353. [CrossRef]

104. Singh, A.L.; D'onofrio, B.M.; Slutske, W.S.; Turkheimer, E.; Emery, R.E.; Harden, K.P.; Heath, A.C.; Madden, P.A.F.; Statham, D.J.; Martin, N.G. Parental depression and offspring psychopathology: A children of twins study. Psychol. Med. 2011, 41, 1385-1395. [CrossRef] 
105. Abela, J.R.Z.; Skitch, S.A.; Auerbach, R.P.; Adams, P. The impact of parental borderline personality disorder on vulnerability to depression in children of affectively ill parents. J. Pers. Disord. 2005, 19, 68-83. [CrossRef] [PubMed]

106. Swartz, H.A.; Shear, M.K.; Wren, F.J.; Greeno, C.G.; Sales, E.; Sullivan, B.K.; Ludewig, D.P. Depression and anxiety among mothers who bring their children to a pediatric mental health clinic. Psychiatr. Serv. 2005, 56, 1077-1083. [CrossRef]

107. Tully, E.C.; Iacono, W.G.; McGue, M. An adoption study of parental depression as an environmental liability for adolescent depression and childhood disruptive disorders. Am. J. Psychiatry 2008, 165, 1148-1154. [CrossRef] [PubMed]

108. Kane, P.; Garber, J. Parental depression and child externalizing and internalizing symptoms: Unique effects of fathers' symptoms and perceived conflict as a mediator. J. Child. Fam. Stud. 2009, 18, 465-472. [CrossRef]

109. Weitzman, M.; Rosenthal, D.G.; Liu, Y.H. Paternal depressive symptoms and child behavioral or emotional problems in the united states. Pediatrics 2011, 128, 1126-1134. [CrossRef]

110. Mezulis, A.H.; Hyde, J.S.; Clark, R. Father involvement moderates the effect of maternal depression during a child's infancy on child behavior problems in kindergarten. J. Fam. Psychol. 2004, 18, 575-588. [CrossRef] [PubMed]

111. Beck, C.T. Maternal depression and child behaviour problems: A meta-analysis. J. Adv. Nurs. 1999, 29, 623-629. [CrossRef]

112. Gross, D.; Conrad, B.; Fogg, L.; Willis, L.; Garvey, C. A longitudinal-study of maternal depression and preschool children's mental-health. Nurs. Res. 1995, 44, 96-101. [CrossRef]

113. Turney, K. Pathways of disadvantage: Explaining the relationship between maternal depression and children's problem behaviors. Soc. Sci. Res. 2012, 41, 1546-1564. [CrossRef]

114. Silberg, J.L.; Maes, H.; Eaves, L.J. Genetic and environmental influences on the transmission of parental depression to children's depression and conduct disturbance: An extended Children of Twins study. J. Child. Psychol. Psychiatry 2010, 51, 734-744. [CrossRef]

115. Murray, L.; Cooper, P.J. The impact of postpartum depression on child development. Int. Rev. Psychiatry 1996, 8, 55-63. [CrossRef]

116. Stein, A.; Netsi, E.; Lawrence, P.J.; Granger, C.; Kempton, C.; Craske, M.G.; Nickless, A.; Mollison, J.; Stewart, D.A.; Rapa, E.; et al. Mitigating the effect of persistent postnatal depression on child outcomes through an intervention to treat depression and improve parenting: A randomised controlled trial. Lancet Psychiat. 2018, 5, 134-144. [CrossRef]

117. Ramchandani, P.G.; Stein, A.; O'Connor, T.G.; Heron, J.; Murray, L.; Evans, J. Depression in men in the postnatal period and later child psychopathology: A population cohort study. J. Am. Acad. Child. Adolesc. Psychiatry 2008, 47, 390-398. [CrossRef]

118. Quarini, C.; Pearson, R.M.; Stein, A.; Ramchandani, P.G.; Lewis, G.; Evans, J. Are female children more vulnerable to the long-term effects of maternal depression during pregnancy? J. Affect. Disord. 2016, 189, 329-335. [CrossRef]

119. Agorastos, A.; Pittman, J.O.E.; Angkaw, A.C.; Nievergelt, C.M.; Hansen, C.J. The cumulative effect of different childhood trauma types on self-reported symptoms of adult male depression and PTSD, substance abuse and health-related quality of life in a large active-duty military cohort. J. Psychiatr. Res. 2014, 58, 46-54. [CrossRef] [PubMed]

120. Bailer, J.; Witthoft, M.; Wagner, H.; Mier, D.; Diener, C.; Rist, F. Childhood maltreatment is associated with depression but not with hypochondriasis in later life. J. Psychosom. Res. 2014, 77, 104-108. [CrossRef] [PubMed]

121. Harkness, K.L.; Lumley, M.N.; Truss, A.E. Stress generation in adolescent depression: The moderating role of child abuse and neglect. J. Abnorm. Child. Psychol. 2008, 36, 421-432. [CrossRef] [PubMed]

122. Hovens, J.G.F.M.; Giltay, E.J.; Spinhoven, P.; van Hemert, A.M.; Penninx, B.W.J.H. Impact of childhood life events and childhood trauma on the onset and recurrence of depressive and anxiety disorders. J. Clin. Psychiat. 2015, 76, 931-938. [CrossRef]

123. Schoedl, A.F.; Costa, M.C.P.; Mari, J.J.; Mello, M.F.; Tyrka, A.R.; Carpenter, L.L.; Price, L.H. The clinical correlates of reported childhood sexual abuse: An association between age at trauma onset and severity of depression and PTSD in adults. J. Child. Sex. Abus. 2010, 19, 156-170. [CrossRef]

124. Fletcher, J.M. Childhood mistreatment and adolescent and young adult depression. Soc. Sci. Med. 2009, 68, 799-806. [CrossRef]

125. Arnow, B.A.; Blasey, C.M.; Hunkeler, E.M.; Lee, J.; Hayward, C. Does gender moderate the relationship between childhood maltreatment and adult depression? Child. Maltreat. 2011, 16, 175-183. [CrossRef] [PubMed]

126. Huh, H.J.; Kim, K.H.; Lee, H.K.; Chae, J.H. The relationship between childhood trauma and the severity of adulthood depression and anxiety symptoms in a clinical sample: The mediating role of cognitive emotion regulation strategies. J. Affect. Disord. 2017, 213, 44-50. [CrossRef] [PubMed]

127. Carvalho Fernando, S.; Beblo, T.; Schlosser, N.; Terfehr, K.; Otte, C.; Löwe, B.; Wolf, O.T.; Spitzer, C.; Driessen, M.; Wingenfeld, K. The impact of self-reported childhood trauma on emotion regulation in borderline personality disorder and major depression. $J$. Trauma Dissociation 2014, 15, 384-401. [CrossRef] [PubMed]

128. Ding, H.S.; Han, J.; Zhang, M.; Wang, K.G.; Gong, J.L.; Yang, S.B. Moderating and mediating effects of resilience between childhood trauma and depressive symptoms in Chinese children. J. Affect. Disord. 2017, 211, 130-135. [CrossRef]

129. Poole, J.C.; Dobson, K.S.; Pusch, D. Childhood adversity and adult depression: The protective role of psychological resilience. Child. Abuse Negl. 2017, 64, 89-100. [CrossRef]

130. Hovens, J.G.F.M.; Giltay, E.J.; van Hemert, A.M.; Penninx, B.W.J.H. Childhood maltreatment and the course of depressive and anxiety disorders: The contribution of personality characteristics. Depress. Anxiety 2016, 33, 27-34. [CrossRef]

131. Spinhoven, P.; Elzinga, B.M.; Van Hemert, A.M.; de Rooij, M.; Penninx, B.W. Childhood maltreatment, maladaptive personality types and level and course of psychological distress: A six-year longitudinal study. J. Affect. Disord. 2016, 191, 100-108. [CrossRef]

132. Miu, A.C.; Bilc, M.I.; Bunea, L.; Szentagotai-Tatar, A. Childhood trauma and sensitivity to reward and punishment: Implications for depressive and anxiety symptoms. Pers. Individ. Dif. 2017, 119, 134-140. [CrossRef] 
133. Kounou, K.B.; Bui, E.; Dassa, K.S.; Hinton, D.; Fischer, L.; Djassoa, G.; Birmes, P.; Schmitt, L. Childhood trauma, personality disorders symptoms and current major depressive disorder in Togo. Soc. Psychiatry Psychiatr. Epidemiol. 2013, 48, $1095-1103$. [CrossRef]

134. Alto, M.; Handley, E.; Rogosch, F.; Cicchetti, D.; Toth, S. Maternal relationship quality and peer social acceptance as mediators between child maltreatment and adolescent depressive symptoms: Gender differences. J. Adolesc. 2018, 63, 19-28. [CrossRef]

135. Harper, F.W.K.; Arias, I. The role of shame in predicting adult anger and depressive symptoms among victims of child psychological maltreatment. J. Fam. Violence 2004, 19, 367-375. [CrossRef]

136. Powers, A.; Ressler, K.J.; Bradley, R.G. The protective role of friendship on the effects of childhood abuse and depression. Depress. Anxiety 2009, 26, 46-53. [CrossRef] [PubMed]

137. Kim, J.S.; Jin, M.J.; Jung, W.; Hahn, S.W.; Lee, S.H. Rumination as a mediator between childhood trauma and adulthood depression/anxiety in non-clinical participants. Front. Psychol. 2017, 8, 597. [CrossRef] [PubMed]

138. Wu, Q.L.; Chi, P.L.; Lin, X.Y.; Du, H.F. Child maltreatment and adult depressive symptoms: Roles of self-compassion and gratitude. Child. Abuse Negl. 2018, 80, 62-69. [CrossRef] [PubMed]

139. Korkeila, J.; Vahtera, J.; Nabi, H.; Kivimaki, M.; Korkeila, K. Childhood adversities, adulthood life events and depression. J. Affect. Disord. 2010, 127, 130-138. [CrossRef]

140. Uhl, K.; Halpern, L.F.; Tam, C.; Fox, J.K.; Ryan, J.L. Relations of emotion regulation, negative and positive affect to anxiety and depression in middle childhood. J. Child. Fam. Stud. 2019, 28, 2988-2999. [CrossRef]

141. Hopfinger, L.; Berking, M.; Bockting, C.L.H.; Ebert, D.D. Emotion regulation mediates the effect of childhood trauma on depression. J. Affect. Disord. 2016, 198, 189-197. [CrossRef] [PubMed]

142. John, S.G.; Cisler, J.M.; Sigel, B.A. Emotion regulation mediates the relationship between a history of child abuse and current PTSD/depression severity in adolescent females. J. Fam. Violence 2017, 32, 565-575. [CrossRef]

143. Rodman, A.M.; Jenness, J.L.; Weissman, D.G.; Pine, D.S.; McLaughlin, K.A. Neurobiological markers of resilience to depression following childhood maltreatment: The role of neural circuits supporting the cognitive control of emotion. Bio. Psychiatry 2019, 86, 464-473. [CrossRef] [PubMed]

144. World Health Organization (WHO). Depression. Fact Sheet. Available online: http://www.who.int/mediacentre/factsheets/fs3 69/en/ (accessed on 11 October 2020).

145. Chan, E.Y.Y.; Lam, H.C.Y.; So, S.H.W.; Goggins, W.B.; Ho, J.Y.; Liu, S.D.; Chung, P.P.W. Association between Ambient Temperatures and Mental Disorder Hospitalizations in a Subtropical City: A Time-Series Study of Hong Kong Special Administrative Region. Int. J. Env. Res. Pub. He. 2019, 15, 754. [CrossRef] [PubMed]

146. Noelke, C.; McGovern, M.; Corsi, D.J.; Jimenez, M.P.; Stern, A.; Wing, I.S.; Berkman, L. Increasing ambient temperature reduces emotional well-being. Environ. Res. 2016, 151, 124-129. [CrossRef] [PubMed]

147. Chen, N.T.; Lin, P.H.; Guo, Y.L.L. Long-term exposure to high temperature associated with the incidence of major depressive disorder. Sci. Total Environ. 2019, 659, 1016-1020. [CrossRef] 